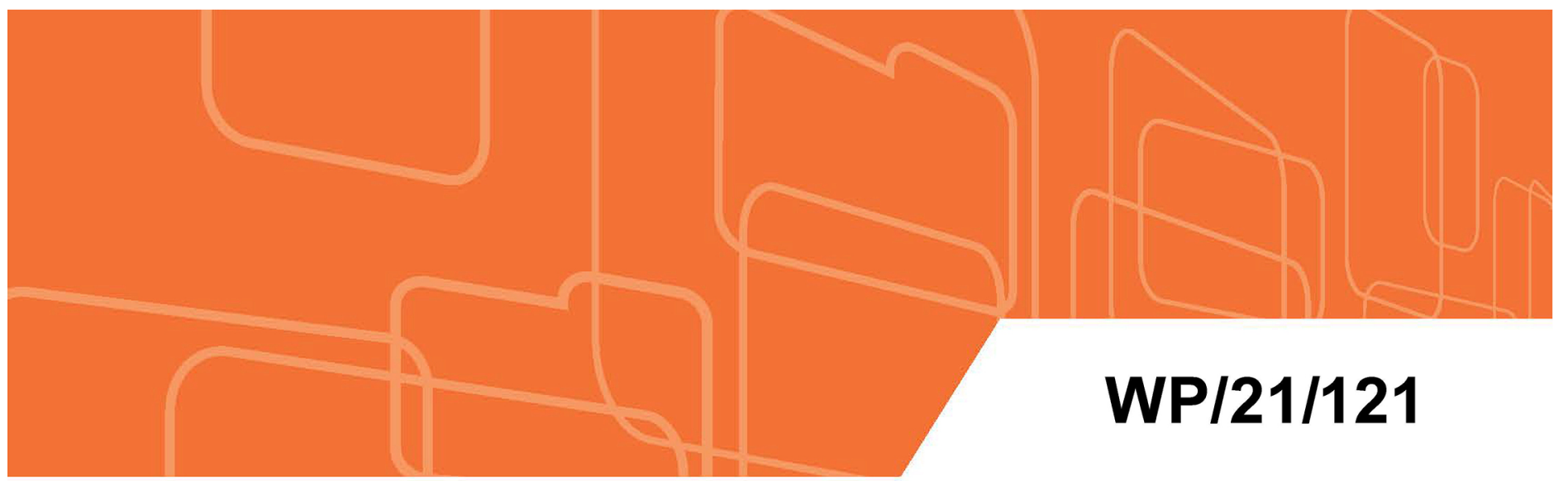

IMF Working Paper

\title{
Austerity and Elections
}

by Alberto Alesina, Gabriele Ciminelli, Davide Furceri, and Giorgio Saponaro

IMF Working Papers describe research in progress by the author(s) and are published to elicit comments and to encourage debate. The views expressed in IMF Working Papers are those of the author(s) and do not necessarily represent the views of the IMF, its Executive Board, or IMF management. 


\title{
IMF Working Paper
}

Asia and Pacific Department

\section{Austerity and Elections ${ }^{1}$}

\section{Prepared by Alberto Alesina ${ }^{2+}$, Gabriele Ciminelli ${ }^{3}$, Davide Furceri ${ }^{4}$, Giorgio Saponaro ${ }^{5}$ Authorized for distribution by Shanaka Jayanath Peiris}

April 2021

\begin{abstract}
IMF Working Papers describe research in progress by the author(s) and are published to elicit comments and to encourage debate. The views expressed in IMF Working Papers are those of the author(s) and do not necessarily represent the views of the IMF, its Executive Board, or IMF management.
\end{abstract}

\begin{abstract}
Conventional wisdom holds that voters punish governments that implement fiscal austerity. Yet, most empirical studies, which rely on ex-post yearly austerity measures, do not find supportive evidence. This paper revisits the issue using action-based, real-time, ex-ante measures of fiscal austerity as well as a new database of changes in vote shares of incumbent parties. The analysis emphasizes the importance of the 'how' - whether austerity is done via tax hikes or expenditure cuts - and the 'who'-whether it is carried out by left- vs. rightleaning governments. Our main finding is that tax-based austerity carries large electoral costs, while the effect of expenditure-based consolidations depends on the political-leaning of the government. An austerity package worth 1\% of GDP, carried out mostly through tax hikes, reduces the vote share of the leader's party by about $7 \%$. In contrast, expenditure-based austerity is detrimental for left- but beneficial for right-leaning governments. We also find that the electoral cost of austerity - especially tax hikes - can be contained if it is implemented during good economic times.
\end{abstract}

JEL Classification Numbers: D72, E62, H62, O47.

Keywords: Austerity, Ideology, Vote share, Tax hikes, Expenditure cuts.

Author's E-Mail Address: gabriele.ciminelli@asb.edu.my; DFurceri@imf.org; giorgiosaponaro@g.harvard.edu.

\footnotetext{
${ }^{1}$ In honor of Alberto Alesina, a mentor and a friend. We thank Robert Barro, Travers Child, Carlo Favero, Viktar Fedaseyeu, Carlos Goncalves, Nicola Gennaioli, Massimo Giuliodori, Greg Mankiw, Paul Pelzl, Paolo Surico, Lawrence Summers and Sweder van Wjinbergen for helpful comments and suggestions. We are also grateful for comments from seminar participants at the Asia School of Business, China Europe International Business School, University of Amsterdam, International Monetary Fund and Banca d'Italia. The views expressed in this paper are those of the authors and do not represent those of the IMF nor the OECD.

${ }^{2+}$ Harvard University and IGIER Bocconi.

${ }^{3}$ Asia School of Business and Organisation for Economic Co-operation and Development (gabriele.ciminelli@asb.edu.my).

${ }^{4}$ International Monetary Fund.

${ }^{5}$ Harvard University.
} 


\section{Table of Contents}

I. Introduction ......................................................................................

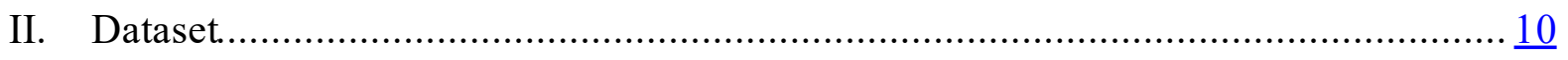

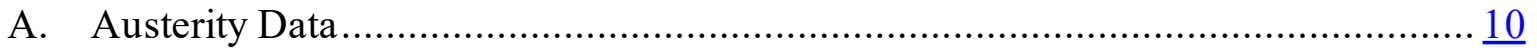

Construction of Austerity Variables.................................................... 11

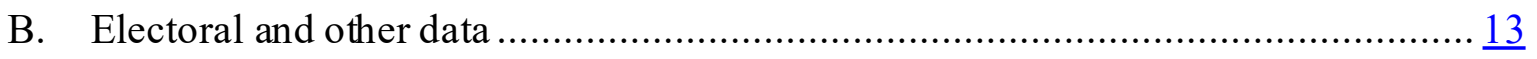

III. Who Adopts What Type of Austerity and When ........................................... 15

IV. Econometric Specifications........................................................... 17

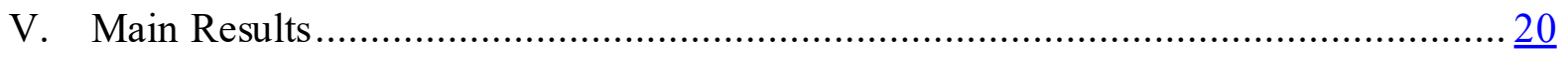

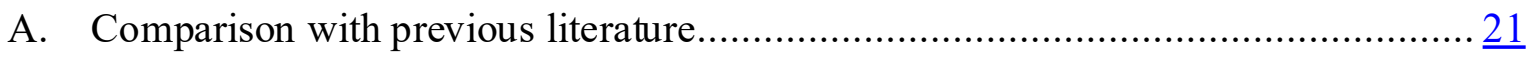

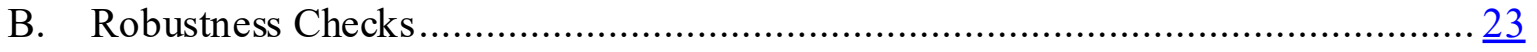

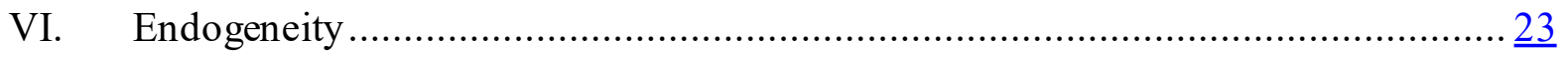

A. Timing of Austerity Announcements...................................................... 24

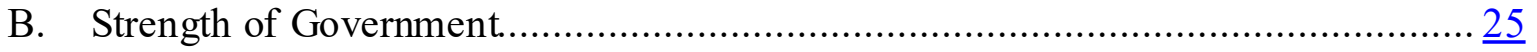

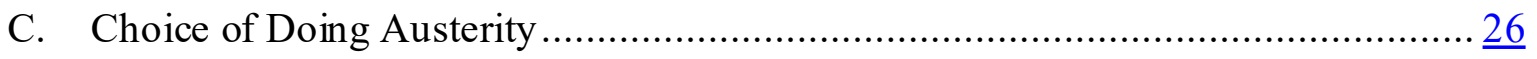

D. Inverse propensity score weighting..................................................... 27

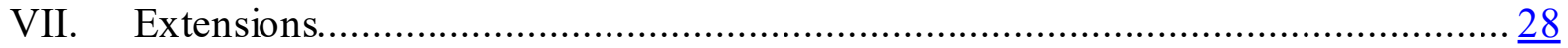

A. The Response of the Economy to Austerity …........................................ 29

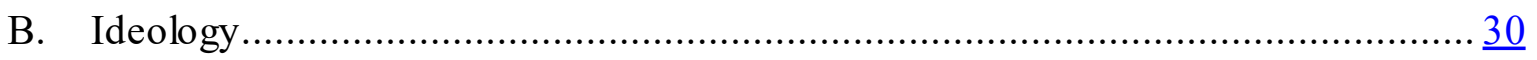

C. Macroeconomic Conditions at the Time of Announcements............................. 31

D. Austerity and the Probability of Early Fall of the Government......................... $\underline{32}$

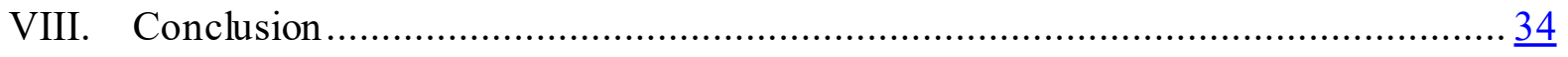

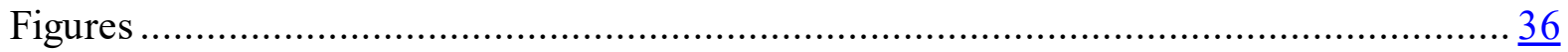

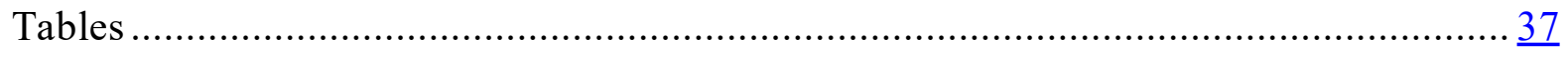

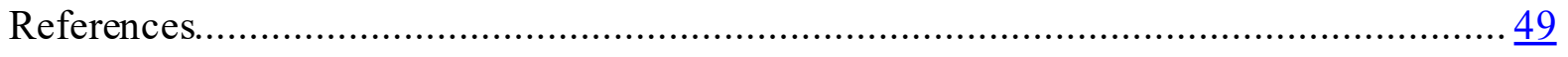

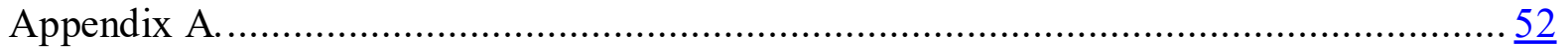

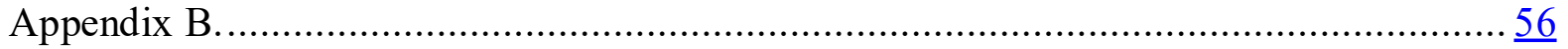

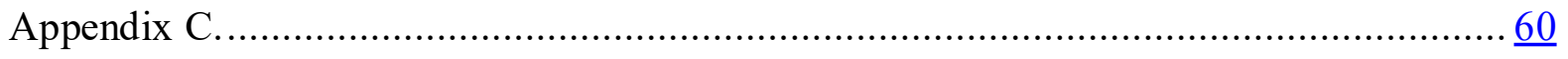




\section{INTRODUCTION}

Fiscal austerity—reducing deficits by cutting expenditures or raising revenues—is often needed to bring the government debt to sustainable levels. A sustainable debt in turn insulates countries from interest rate shocks and increases their capacity to respond to crises. Yet, a strongly held conventional wisdom holds that any government that reduces the budget deficit by raising taxes or cutting expenditures is punished at the polls. This belief, however, is not supported by existing empirical evidence. In what is probably the most comprehensive empirical study on this point, Brander and Drazen (2008) find a weak opposite effect: governments reducing deficits are slightly rewarded.

This paper reassesses the conventional wisdom that austerity carries an electoral cost by making important progresses in the identification of the political effects of fiscal austerity and highlighting the importance of the 'how'-whether austerity is done via tax hikes or expenditure cuts—and the 'who'-whether it is carried out by left- vs. right-leaning governments. As we show, these elements are key to reconcile the empirical evidence with the conventional wisdom.

Previous studies have typically used ex-post yearly fiscal data on the deficit-to-GDP ratio to examine the electoral effects of austerity. Since elections and changes in governments can take place at any time of the year, it is close to impossible to exactly determine which government is responsible for austerity using these data. Moreover, the budget deficit is a grossly imperfect measure of fiscal austerity, as it is endogenous to the state of the economy. ${ }^{6}$

\footnotetext{
${ }^{6}$ The deficit-to-GDP ra tio may go down just before an election not because a government has a dopted a usterity, but simply because the economy is in a boom. Conversely, the deficit may go up despite the introduction of a usterity policies because the economy is deteriorating. In such a situation, a researcher rely ing on ex-post fiscal data may baselessly conclude that expan sionary fiscal policy (and not austerity or wea ker growth) is harm ful for re-election.
} 
We make important progresses in these respects by using a real-time narrative dataset of exante austerity plans. The use of policy records allows us to (i) include episodes in which the budget worsened despite austerity, while excluding those in which it improved because of a booming economy, (ii) identify the precise timing of each austerity plan to match it to the government that introduced it, and (iii) distinguish between tax hikes and expenditure cuts.

Combining our narrative austerity dataset with novel data on political parties' vote shares and ideological leaning, we find strong evidence supporting the conventional wisdom that (some) austerity plans are politically costly. Our key finding is that tax-based austerity carries large electoral costs, while expenditure-based consolidations are neutral on average. An austerity package worth $1 \%$ of GDP, carried out mostly through tax hikes, reduces the vote share of the leader's party by about 7\%. Note that Alesina et al. (2019) show that tax-based austerity has much stronger negative effects on GDP growth than expenditure cuts, but the results described above hold even controlling for growth —and, therefore, for the effect of austerity on the economy.

Our second set of results highlights the importance of ideology: the negative effect of tax-based consolidations is stronger for right-leaning governments, while expenditure-based austerity is detrimental for left- but beneficial for right-leaning ones. These asymmetries plausibly reflect differences in the preferred degree of government redistribution among voters of parties at opposite ends of the political spectrum.

We also investigate whether the timing of austerity in relation to the business cycle matters for its electoral outcomes and find that it does. The electoral cost of austerityespecially tax hikes - is higher (lower) when implemented during bad (good) economic times. These results are consistent with those of Alesina et al. (2020) that show that economic reforms 
are penalized during contractions but are often rewarded in expansions and suggest that voters may have difficulties distinguishing between underlying economic conditions and the growth effects of some government policies. We also find that the asymmetric effects of expenditurebased consolidations depending on ideology are larger in good economic times.

Obviously, endogeneity problems loom large. For example, governments which are reasonably sure to win the election may afford to implement austerity and are indeed re-elected despite, not because of, austerity. There are three main relevant endogenous choices a government is faced with: (i) whether to engage in austerity policies at all; (ii) when to do it during the electoral term; and (iii) whether to base austerity on tax hikes or expenditure cuts (the composition of the austerity plan). Despite our best attempts to control for selection and government strength, it is close to impossible to solve these issues convincingly, and we must acknowledge that the empirical results on the effects of austerity on elections may be biased because of this endogeneity. As we show, however, we find evidence of government strategic behavior that may suggest that the electoral effects of austerity are larger than those estimated.

First, we observe that governments tend to avoid announcing austerity close to elections and concentrate austerity plans at the beginning of their mandate, when they have stronger political support and the next election is relatively far away so that electoral considerations are less important. Second, we find that weak governments-perhaps recognizing their vulnerability or believing the conventional wisdom that austerity is costly — tend to implement less austerity than strong ones. Both elements suggest that our results are likely to be a conservative estimate of the electoral effects of austerity. ${ }^{7}$

\footnotetext{
${ }^{7}$ If the true effect of austerity on the electoraloutcome was negative, a strategic government would try to adjust the budget when the cost of doing so (the marginal change in the vote share) is low, which occurs when the government is popular. As a result, the estimated coefficient would be biased upward. If the true coefficient, instead, was positive, then a strategic government would exploit this rela tion, a nd governments that are less sure
} 
We try to address endogeneity as follows. In all our estimations we include political party fixed effects to control for parties' specific characteristics_including ideology—that may influence the choice of whether and how to engage in austerity. We also perform other exercises. First, we consider the endogenouschoice of when in the electoral term to do austerity and focus on the sample of consolidation plans that are announced in the first year of the government's term is in office-which is when strategic electoral considerations are likely to be less of a concern. ${ }^{8}$ The results are even sharper than our baseline and confirm the main finding that tax-based consolidations decrease the vote share of incumbent parties while expenditure-based ones are neutral, on average. Second, we control for the strength of the government and find similar results. We also find the electoral cost of tax-based austerity to be significantly larger for weaker governments, which again suggests that our baseline estimate may be a lower bound of the true electoral cost of tax-based austerity. Third, we directly control for the choice of whether to introduce austerity and whether to carry it out through tax hikes or expenditure cuts. The results are in line with our baseline findings: the marginal effect of tax-based austerity — conditional on carrying out austerity — is negative and significant, while that of expenditure-based austerity is insignificant.

Finally, to further address endogeneity, we adapt the approach proposed by Jordà and Taylor (2016) to achieve identification of causal effects of austerity. We employ an augmented inverse probability weighting (AIPW) estimation which gives less weight to austerity episodes

of being re-elected would have a greater incentive to implement austerity. In such a case the estimated coefficient would be bia sed downward.

${ }^{8}$ Another element of strategic selection is tha t governments which perceive a higher risk of ending their mandate prematurely, independently of a usterity, will consolidate early in the term, while governments less a fraid of it would care less, and would carry it out rela tively la ter in the term. 
that can be predicted based on macroeconomic and political variables. The results confirm that tax-based austerity plans carry electoral costs, while expenditure-based ones do not on average.

Our analysis has interesting implications regarding recent evidence provided in Passarelli and Tabellini (2017) and Ponticelli and Voth (2020). ${ }^{9}$ These papers show that expenditure cuts generate uprisings, demonstrations and street actions. The former, which is more directly related to ours because its data are on a more recent period and more consistent with our sample, finds that budget cuts lead to social unrest. The latter uncovers a positive and significant association of demonstrations, political assassinations, and general strikes with expenditure cuts, but not with tax hikes. Expenditure cuts may indeed affect certain constituencies, such as farmers, students, public employees, specific industries or regions. These groups may revolt but the median voter is, however, the taxpayer. Her only available political response is voting, and she votes against tax hikes. Thus, our result suggest that it is possible to have street demonstrations against expenditure cuts and electoral victories (or lack of defeats) of governments which implement them.

More generally, these considerations are related to the issue of localized benefits and generalized costs. Preventing a budget cut is a localized benefit, paying for it with a tax hike is usually a generalized cost. Weingast et al. (1981) first made the point that representative legislatures give priorities in the budget to projects for districts that they represent, arguing that this strategy, commonly referred to as "pork barrel expenditure", increases in the number of electoral districts. Battaglini and Coate (2008) present a theoretical framework of collective fiscal policy choices that encompasses this phenomenon too.

\footnotetext{
${ }^{9}$ The former uses data from 19 OECD countries from 1975 to 2008 while the latter focuses on 24 European countries from 1919 to 2008.
} 
As we discussed earlier, we are not the first to study the effect of austerity on elections. The results of the previous literature, based on ex-post yearly austerity measures, are generally inconclusive. Alesina et al. (1998) find that reductions in the deficit do not predict a future change in government in a sample of advanced economies, while Alesina et al. (2012) do not find any evidence that large fiscal adjustments decrease the probability that a government is replaced by one with different ideology. ${ }^{10}$ Alesina et al. (2019) in Chapter 10 review the literature on this point and provide new results which are again inconclusive: it is hard to find a strong statistical correlation between austerity measures and the electoral fortunes of the incumbent. A related literature has looked at fiscal performance and elections. Peltzman (1992), Brender (2003) and Drazen and Eslava (2003) study the effects of budget deficit on electoral results in state and local elections in, respectively, the United States, Israel and Colombia, and find that voters punish, rather than reward, budget deficits. Brender and Drazen (2008) examine 350 electoral campaigns across 74 countries and find that voters are (weakly) likely to punish rather than reward budget deficits accumulated during the leader's term in office. Relatedly, Arias and Stasavage (2019) study a sample of countries and a timeframe ranging from 1870 to 2011 and show that cuts in expenditures are not associated with government turnover. The main difference between our paper and these studies is that we use a real-time narrative database of ex-ante fiscal measures.

The rest of this paper is organized as follows. Section II discusses the dataset and the construction of our austerity variables. Section III presents some stylized facts on the timing of austerity announcements in the electoral cycle and the characteristics (in terms of ideology and strength) of the governments responsible for them. We describe the empirical framework

\footnotetext{
${ }^{10}$ The former study uses primary deficit, while the latter uses cyclically a dju sted deficit.
} 
in Section IV and present the main results in Section V. Section VI discusses endogeneity issues and how we address them, while in Section VII we present some extensions to the baseline analysis. Section VIII concludes.

\section{Dataset}

Our sample covers 16 advanced economies (Australia, Austria, Belgium, Canada, Denmark, Finland, France, Germany, Ireland, Italy, Japan, Portugal, Spain, Sweden, the United Kingdom and the United States) and spans the 1978-2014 period.

\section{A. Austerity Data}

We use the action-based dataset of Alesina et al. (2019), who rely on a narrative approach à la Romer and Romer (2005) to identify fiscal consolidation plans in 16 OECD countries from 1978 to $2014 .{ }^{11}$ In particular, the dataset covers 3500 different fiscal measures adopted in the context of more than 250 austerity plans. Some of these measures are announced for future implementation (over the 5 subsequent years), while others are implemented within the same announcement year. The data record the budgetary impact (as estimated in the documents that accompany their adoption) of these fiscal measures on total revenues and expenditures relative to a baseline of no policy change.

This dataset has three important advantages for our analysis. The first is that it allows us to determine the exact month of the announcement of each austerity plan decided by the government. This is possible because Alesina et al. (2019) link each plan to the official policy

\footnotetext{
${ }^{11}$ Alesina et al. (2019) build upon Devries et al. (2011).
} 
records used to identify it. We retrieve the precise month of each announcement by reading the policy records and, when these do not contain the announcement date, by conducting other searches on the web. Once the month of announcement is known, we assign the austerity plan to the government that announced (implemented) it. Using standard yearly austerity data this would be impossible, since elections and changes in governments take place at any time of the year.

The second advantage of the dataset of Alesina et al. (2019) is that it embraces the notion that austerity measures are typically introduced by means of multi-year plans. This dynamic nature is such that austerity plans affect voters' expectations about the future. Since the dataset lists both measures for immediate and future implementation, we can account for policies that are yet to be implemented but that still influence voters' choices at the election.

The third advantage is that the dataset only covers discretionary measures. Focusing on discretionary actions is important as, from an electoral standpoint, a deficit reduction obtained because growth was strong is very different from a deficit reduction due to austerity measures. Moreover, only plans whose objective is not to influence the state of the real economy are included in the dataset. Most plans are thus driven by the need to reduce the deficit or the stock of debt, or to correct a long-term dynamic of a budgetary chapter. The exogeneity of our austerity measure to output eliminates one potential source of endogeneity, and it also allows us to test whether austerity policies have effects on electoral variables through their effects on output. We provide more details on the dataset of Alesina et al. (2019) in Appendix A.

\section{Construction of Austerity Variables}

To construct our fiscal variables, we first assign each austerity plan recorded in Alesina et al. (2019) to the government that announced it. For each plan, we then calculate the overall 
budgetary impact expected in real-time over a five-year period - that is, considering both measures for immediate and future implementation — as a fraction of GDP. ${ }^{12,13}$

Following Alesina et al. (2019) and a plethora of other empirical studies, we distinguish between tax- and expenditure-based plans. We classify each austerity plan as either tax- or expenditure-based, based on whether $55 \%$ or more of the overall consolidation effort is achieved via tax hikes or expenditure cuts, respectively. By doing so, we exclude from the analysis a few plans that are close of $50 / 50 \%$ because the classification of these plans would be arbitrary. ${ }^{14}$ Finally, to obtain the key regressors that we use in the analysis, we sum up all consolidation plans announced during the government term, still distinguishing between taxand expenditure-based plans. ${ }^{15}$

To sum up, our two main austerity variables measure the current and expected future budgetary impact of all new tax-and expenditure-based consolidation plans decided during the government's term. Therefore, we also consider measures that are announced and not yet implemented when voters head to the poll, which are likely to influence their preferences as much as the plans that are already implemented.

\footnotetext{
${ }^{12}$ As in Alesina et al. (2019), we use GNP and not GDP for Ireland.

${ }^{13}$ We only consider theimpact of permanent ra ther than one-off changes in fiscal policy. This is because one-off changes should a rguably have smaller effects than permanent changes and are too few to separately estimate their effects. The results are robust to also including one off measure and treating them as permanent.

${ }^{14}$ For a more detailed discussion, see Alesina et al. (2019). The main results of this paper are robust if $50 \%$ or $60 \%$ thresholds were used instead of $55 \%$ to define tax-a nd expenditure-based plans (see Table C2 in Appendix C).

${ }^{15}$ Aggregating all plans in the same government term implies that tax-and expenditure-based plans a re not mutually exclusive in one term. This requires the a dditional a ssumption that fiscal plans a renot correlated a cross different time periods, i.e. that a tax (expenditure)-based plan at period $t$ predicts an expenditure(tax)-based plan at $t+k$, with $t$ and $t+k$ being in the same government term. Although the correlation between tax-and expenditurebased plans implemented in different years of the same government term is indeed low, in a robustness check we also consider alternative variables constructed dropping this assumption, therefore considering tax- and expenditure-based plans that a re mutually exclusive within one term. Our results a re robust to this altemative specification (see Table C2 in Appendix C).
} 
In contrast, we assume that the implementation of austerity measures announced by a previous government does not impact the electoral outcome of the government in charge. Another approach would be to consider only measures that are implemented in the term, consistent with the rationale that the current government must be held responsible even for policies announced by previous governments that it did not decide to overturn. Our results are also robust to this approach, as we show in a robustness check.

\section{B. Electoral and other data}

In this section, we summarize the construction of our electoral variables. We provide more details, together with descriptive statistics, in Appendix B. Electoral data come from multiple sources. We use the electoral dataset compiled by Alesina et al. (2020) to retrieve the dates of each general election, as well as the start and end dates of each government's term in office. ${ }^{16}$ For parliamentary systems - that is, all countries in our sample except France and the United States - we rely on Wikipedia and Doring and Manow (2019) to reconstruct the party or coalition of parties supporting the government.

In parliamentary systems there can be multiple governments within the same legislature. Hence, we construct a 'party term' variable that captures the period featuring the same governing party (or coalition of parties) within the same legislature. ${ }^{17}$ Governments

\footnotetext{
${ }^{16}$ All countries in our sample, except France and the United States, have parliamentary systems in which the head of sta te has largely a ceremonial role. Hence, we only consider parlia mentary elections for these countries. For the United States, we only consider presidential elections as the president is also the head of government. In France, voters elect both the president and the parliament, and both the president and the head of govemment have executive powers. However, since presidential elections typically attract a higher turnout, we focus on presidential elections. There are also five interim governments in our sample (Boeynants and Verhosdaft III in Belgium, Aoki and Ito in Japan and Pintasilgo in Portugal), three technocratic governments (Cia mpi, Dini and Monti governments in Italy), and one case in which the main party supporting the government did not run at the next election (the Amato I cabinet in Italy). These governments are excluded.

${ }^{17}$ Governing parties are defined as such if they hold Cabinet seats in the government (Ministries).
} 
within the same legislature that are not supported by the same parties are treated as belonging to different party terms. In the case of presidential systems, given that the president stays on for a fixed amount of time, we just retrieve the party to which he or she belongs and record the party term as the term of the president. This party term variable serves as the basis for our analysis, in that we investigate the effect of austerity policies announced during the party term on the electoral performance of the party(ies) supporting the government.

Next, we rely on the dataset of Doring and Manow (2019) to collect information on the vote share obtained by the party of the chief executive at the two elections defining the start and the end of the legislature and compute its percent change. ${ }^{18} \mathrm{We}$ also construct a variable measuring the vote share change of the overall coalition of governing parties, as well as similar other variables to be used in some robustness checks - the vote share change at the previous election, the percent change in parliamentary seats share, and the election turnout. Finally, from Doring and Manow (2019), we also source a variable measuring the political leaning of the leader's party (ideology) and normalize it to range between -10 and 10 . This variable takes value 0 for the center of the political spectrum and higher (lower) values for more right- (left)leaning parties.

Our database is complemented by other macroeconomic data that we collect to run some robustness checks and extensions. From the IMF World Economic Outlook (Spring 2019 Edition), we source real per capita GDP growth, the unemployment rate, the budget balance,

\footnotetext{
${ }^{18}$ Our approach using the vote share change improves upon earlier analyses relying on dummy variables to measure political effects of government actions. Brender and Drazen (2008) use a 0/1 dummy taking value 1 when the chief executive is re-elected and 0 otherwise. The same approach is a lso followed in Peltzman (1992), Brender (2003), Drazen and Eslava (2010), and Jones, Meloni and Tommasi (2012) to answer similar research questions. Using the change in the vote (or sea ts) share allows to more precisely quantify the electoral effects of austerity. Using a continuous rather than a dichotomous variable has also the advantage to estimate the specification using simply OLS — rather than Probit or Logit — and to include party fixed effects in the regression without sa crificing a ny observation.
} 
the inflation rate and the 10 -year real government bond yield. From the OECD Statistical Database, we source data on national disposable income (in constant prices and national currency). We linearly interpolate these variables to have them at the monthly frequency and calculate (i) their value in the month of the election, (ii) their averages over the entire duration of the government term, and (iii) their change both during the last 12 months and over the entire government term. Further, we source indicators of economic liberalization in the areas of capital account transactions, trade tariff barriers, domestic finance and labor market from Alesina et al. (2020) and calculate their change between the first and last year of the government term.

\section{Who Adopts What TyPE OF AUSTERITY AND WhEN}

This section presents a few key stylized facts on the type and timing of austerity plans adopted by different governments. In short, these stylized facts suggest that: (i) governments tend to avoid announcing austerity close to elections and concentrate austerity plans at the beginning of their mandate, when they have stronger political support; (ii) weak governments - perhaps recognizing their vulnerability - tend to implement less austerity than strong ones; and (iii) closer to elections, the type of austerity depends on the government's ideology: right-leaning governments prefer expenditure cuts over tax increases, while the opposite holds for leftleaning governments. In the rest of this section we discuss these stylized facts more in detail.

We begin by exploring whether there exists a systematic pattern in the timing of austerity announcements. In Figure 1, we plot the size of the average austerity announcement in each of the first four years of the government term-for the overall consolidation effort 
(Panel A) and for tax- and expenditure-based announcements (Panel B). ${ }^{19}$ The figure provides suggestive evidence that austerity is larger in the first than any other year of the term. This is mostly driven by tax-based consolidations, which are almost four times as large in the first as in the fourth year of the term. In contrast, expenditure-based consolidations do not seem to follow a systematic pattern over the government term, on average. ${ }^{20}$ Behind these average patterns, there are some important differences between left- and right-leaning governments: while, for both left- and right-leaning governments, tax-based consolidations decline as the election approaches, expenditure-based ones increase close to an election for right-leaning government whereas they gradually decline over the term for left-leaning governments (Figure 2). ${ }^{21,22}$

We next explore whether the choice to carry out austerity or not depends on the strength of the government's mandate. For this purpose, we consider the change in the vote share obtained by the incumbent party in the election that brought it to power and look at austerity plans announced by strong and weak governments. We distinguish among them based on whether the change in the vote share is above or below the median. The statistics reported in Table 1 suggest that strong governments carry out austerity plans more frequently and adopt larger packages than weak ones on average. This holds both for tax- and expenditure-based

\footnotetext{
${ }^{19}$ If the term starts in the last six months of the year, we consider the start year of the term to also include the following year. Similarly, if the tem ends in the first six months of the year, we consider the last year to also include the previous one. To ensure a fair comparison, we scale each announcement in the first and last year of the term by the total number of months in those two years.

${ }^{20}$ We also observe that expenditure-based austerity is typically more frequent (and/or larger) than tax-based a usterity, a s also noted in Alesina et al. (2019).

${ }^{21}$ We define left- (right-)leaning governments as those having a score respectively below (above) 0 for the ideology va riable.

${ }^{22}$ Note that the average expenditure-based announcement for right-leaning governments is sta tistically different from that of left-leaning governments in the election year. The null hypothesis that tax-based austerity a nnouncements in the election year by left-and right-leaning governments a re equal cannot be rejected only by a small margin.
} 
austerity and both across the entire government term and the first year in office. In particular, in the first year, when our measure of strength better captures the popularity of the government just elected, strong governments carry out austerity packages that are about $2 \frac{1}{2}$ times larger than those adopted by weak ones (statistically significant at the $95 \%$ confidence interval). We further differentiate based on ideology and find that the strength of the mandate matters for both left- and right-leaning governments. However, the difference is more pronounced among the former and especially in the case of expenditure-based austerity.

Overall, these findings suggest that strategic selection might indeed be at play: governments recognize that austerity is unpopular, and they try to announce it when they are relatively stronger. ${ }^{23} \mathrm{We}$ explicitly address this issue when we examine the electoral effects austerity in the first year of the government term and distinguish between governments with strong and week mandate.

\section{ECONOMETRIC SPECIFICATIONS}

To empirically analyze the electoral effects of austerity, we regress the percent change of the vote share of the parties supporting the government onto our two austerity variables, respectively measuring the tax- and expenditure-based consolidation plans announced during the term. We include party fixed effects to limit the endogeneity arising from the strategic selection in the announcement and composition of austerity plans depending on the government's ideology. We also include GDP growth at the time of the election, as many other

\footnotetext{
${ }^{23}$ These findings are also in line with Hubscher (2016) and Hubscher and Sattler (2016). The former finds that stra tegic considerations play an important role in the timing and design of fiscal consolidations, while the latter conclude that electorally vulnerable governments strategically a void consolidations towards the end of the legislative term in order to minimize electoral punishment.
} 
papers have shown this variable to be an important predictor of electoral results (for instance, see Brender and Drazen, 2008). The baseline equation that we estimate is as follows:

$$
{ }_{0 \text { Vote }_{i, e}}=\alpha+\gamma_{i j}+\beta T b_{i, e}+\delta S b_{i, e}+\varphi Y_{i, e}+\vartheta Z_{i, e}+\varepsilon_{i, e}
$$

where the subscripts $i$ and $e$ refer respectively to country $i$ and election $e$, while the subscript $i j$ refers to the leader's party $j$ in country $i$; $\%$ Vote $_{i, e}$ is ourdependent variable, which measures the percent change of the vote share of either the coalition of parties supporting the government or the party of the incumbent leader; $\alpha$ is a constant term; $\gamma_{i j}$ are party fixed effects; $T b_{i, e}$ and $S b_{i, e}$ respectively denote the tax-and expenditure-based austerity plans announced during the government term, in \% of GDP; $Y_{i, e}$ is GDP growth at the time of the election; $Z_{i, e}$ is a matrix of controls and additional variables capturing macroeconomic developments and political factors; and finally $\varepsilon_{i, e}$ is an error term assumed to be uncorrelated with the regressors. $\beta$ and $\delta$ are the main coefficients to be estimated. For the estimation, we rely on OLS. Standard errors are computed using the robust estimator of variance.

We then augment Equation (1) to run some extensions to the baseline analysis. In a first extension, we test the hypothesis that the electoral effects of austerity depend on whether (and how much) the government is left- or right-leaning. To do so, we interact our austerity measures with the ideology variable and add these interaction terms to Equation (1). In practice, we estimate the following specification:

$$
\begin{aligned}
& y_{i, e}=\alpha+\gamma_{i j}+\beta T b_{i, e}+\omega T b_{i, e} * \text { Ideology }_{i, e}++\delta S b_{i, e}+\sigma S b_{i, e} * \operatorname{Ideolog}_{i, e}+ \\
& +\varphi Y_{i, e}+\vartheta Z_{i, e}+\varepsilon_{i, e}
\end{aligned}
$$


where Ideology $y_{i, e}$ takes larger positive (negative) values the more right- (left-)leaning is the government. The rest is as in Equation (1).

In a second extension, we investigate whether the electoral effects of austerity policies are affected by the macroeconomic conditions prevailing at the time of the announcement. Drawing from previous literature studying whether austerity tends to have different effects on output growth depending on the state of the business cycle (Auerbach and Gorodnichenko, 2012; Ramey and Zubairy, 2017; Alesina et al., 2019), we test the hypothesis that austerity is better received when it is carried out in good economic times. Since, all else equal, higher taxes and lower government expenditures might decrease disposable incomes, it is reasonable to expect austerity to be more accepted when growth is high and incomes are rising. Moreover, as discussed in Alesina et al. (2020), voters may not be able to distinguish between underlying economic conditions and the effect of policies on economic conditions, therefore penalizing (rewarding) any policy choice during recessions (booms).

The strategy that we follow is to allow for the effects of the fiscal plans adopted during the government term to depend on whether each of these plans was adopted in a boom or in a downturn. In particular, following Auerbach and Gorodnichenko (2012), we first transform standardized output growth, $Z$, into a variable $G(Z)$ ranging between 0 and 1 and increasing in Z. $G$ is defined to be the following logistic function: $G\left(Z_{i, t}\right)=\frac{\exp \left(-\gamma Z_{i, t}\right)}{1+\exp \left(-\gamma Z_{i, t}\right)}$, where the subscripts $i$ and $t$ refer to country $i$ and year $t ; Z_{i, t}$ is the real GDP growth rate, normalized to have zero mean and unit variance within country; and $\gamma$ is a smoothing parameter taking value 1.5. We then interact $G\left(Z_{i, t}\right)$ and 1- $G\left(Z_{i, t}\right)$ with the yearly austerity variables and take the sum of the resulting products over each year of the government term. We label the variables obtained in this way using the superscript $L$ and $H$, to denote austerity announced during 
periods of low and high states of economic growth. We then estimate the following specification (where the notation is as before):

$$
y_{i, e}=\alpha+\gamma_{i j}+\mu T b_{i, e}^{L}+\rho T b_{i, e}^{H}+\theta S b_{i, e}^{L}+\varphi S b_{i, e}^{H}+\tau Y_{i, e}^{H}+\omega Y_{i, e}^{L}+\varepsilon_{i, e}
$$

\section{Main Results}

We begin by estimating a regression including only our tax- and expenditure-based consolidation variables. We then build upon this parsimonious specification by adding, first, the party fixed effects and, second, GDP growth at the time of the election. Other controls are added later in the robustness check exercises. Table 2 presents the estimated effects of tax- and expenditure-based consolidations on the percent change of the vote share of both the party of the incumbent leader (Columns 1-3) and the overall coalition of governing parties (Columns 4-6).

Our main finding is that tax-based consolidations carry large electoral costs, while expenditure-based consolidations are neutral, on average. An austerity package worth $1 \%$ of GDP, carried out mostly through tax hikes, reduces the vote share of the leader'sparty by about $7 \%$ (Column 1). This effect is statistically significant at the $99 \%$ confidence level, it is robust to the inclusion of leader's party fixed effects (Column 2), and it is estimated to be roughly the same when controlling for GDP growth, which, as expected, has itself a significant positive effect on the vote share (Column 3). On the other hand, expenditure-based consolidations do not have statistically significant effects. Note that when we control for growth the effects of tax-based austerity are slightly diminished. This is consistent with the fact that tax-based austerity has more recessionary effects than expenditure-based and suggests that the response 
of growth might be one channel for the effects of tax-based austerity on the incumbent's vote share, although certainly not the only one.

The effects that we estimate are also economically important. The results suggest that a tax-based consolidation plan of about one standard deviation (approximately $1 \%$ of GDP) would decrease the vote share of the incumbent party by about $1 / 2$ standard deviation (approximately 10\%).

Looking at the coefficients estimated for the entire coalition of governing parties (Columns 4-6), we find slightly lower negative effects of tax-based consolidations on the vote share, which suggests that voters hold the party of the incumbent leader as more accountable for austerity policies. To validate this intuition, in Table 3 we report results obtained estimating Equation (1) on the restricted sample of coalition governments, using as dependent variable the percent change in the vote share of (i) the overall coalition, (ii) the party of the incumbent leader, and (iii) the rest of the governing parties. Estimates for the overall coalition and the main party are in line with those of Table 2, while those for the rest of the coalition are not statistically significantly different from zero. These results are consistent with prior findings in the literature on "clarity of responsibility" (Powel and Whitten, 1993). In the remainder of the paper we focus exclusively on the party of the incumbent leader and build upon Column (3) of Table 2 as our baseline specification.

\section{A. Comparison with previous literature}

Our results depart substantially from previous literature, which has not found evidence supporting the conventional wisdom that voters punish governments implementing austerity. As discussed earlier, our approach to identify fiscal austerity adopted by the government in charge differs from previous studies along two main dimensions: the ability to exactly match 
austerity policies with the government that actually implemented (introduced) it, and the use of ex-ante versus ex-post fiscal data. Here, we assess how these methodological differences contribute to the different results that we find.

First, we estimate Equation (1) using austerity variables constructed without precisely matching austerity policies to the government announcing them. This issue may be particularly relevant since austerity announcements are typically very large in the first year of the government and without a careful matching process, austerity measures of a newly elected government may be mistakenly attributed to the previous one. Second, we estimate Equation (1) using ex-post austerity variables - that is, variables constructed using budgetary data on changes in revenues and expenditures. ${ }^{24}$ Since many past studies do not distinguish between tax hikes and expenditure cuts, we perform these exercises both for overall austerity and for tax- and expenditure-based consolidations separately.

Table 4 reports the results. Columns 1-3 report estimates for overall austerity, while Columns 4-6 distinguish between tax- and expenditure-based austerity. For convenience, Columns 1 and 4 report estimates obtained using ex-ante matched fiscal data (our own approach). Columns 2 and 5 show results obtained using ex-ante, but not matched, austerity variables, while Columns 3 and 6 report coefficients estimated using austerity measures derived from ex-post fiscal data.

The results obtained using ex-ante austerity variables that are not matched are qualitatively in line to our baseline, although the negative effect estimated for tax-based consolidations is halved and only marginally statistically significant (Columns 4). In contrast,

\footnotetext{
${ }^{24}$ When using ex-post fiscal data, we define years in which the cyclically a djusted budget improves by more than $1.5 \%$ of GDP a s austerity episodes.
} 
when relying on ex-post fiscal variables and not distinguishing between tax hikes and expenditure cuts (Column 3), we find a statistically positive effect, in line with Brender and Drazen (2008) and others, while we do not find any statistically significant effect when we distinguish between tax hikes and expenditure cuts.

Overall, these results suggest that both the use of ex-ante austerity data and the matching of austerity policies to the actual government announcing them are key to correctly identify the political effects of austerity and reconcile the conventional wisdom that (some) austerity policies carry an electoral cost with the empirical evidence.

\section{B. Robustness Checks}

Next, we assess the sensitivity of our baseline results to a battery of different specifications. In particular, we check that the results (i) are not driven by a single political party or country, (ii) are robust to using alternative variables to measure electoral performance and fiscal austerity, (iii) are similar across different subsamples, and (iv) are robust to the inclusion of several political, macroeconomic and structural control variables. The results from these alternative specifications, which are presented and discussed in detail in Appendix C, confirm the robustness of our baseline results.

\section{ENDOGENEITY}

In this section, we try to address potential sources of endogeneity regarding the timing and the choice of doing austerity. 


\section{A. Timing of Austerity Announcements}

We begin by considering the endogenous choice of when to carry out austerity and only focus on austerity conducted at the beginning of the government's term, when electoral considerations are less relevant for policy formulation. We re-estimate Equation (1) replacing our baseline austerity variables with variables measuring the impact of austerity plans announced in the first year of the government's term. We also estimate a specification for austerity announced in the third year of the term, with the rationale being that if strategic selection were indeed an issue, then the effect of austerity of announced later in the term would be estimated with more bias. ${ }^{25}$ For comparison, we also re-estimate the model only on the subsample of governments that lasted at least over the third year and a specification in which both the first and third year austerity variables enter the regression separately.

Table 5 presents the results. Column 1 reports our baseline (full sample and 'any year') estimates, while Column 2 shows the results for austerity announced during any year of the term in the subsample of governments lasting at least over the third year. Columns 3 and 4 report the results for austerity announced in the first year, estimated respectively on the full sample and the subsample of governments lasting at least over the third year. Column 5 shows results for austerity announced in the third year of the term, while Columns 6 focuses on the first and third year.

Overall, the results confirm that tax-based austerity plans have negative and statistically significant electoral effects, while expenditure-based austerity is neutral. Worth noticing, the effect of tax hikes is larger for plans announced early in the government mandate (first year) when strategic considerations are less important — than closer to elections (third year). This

\footnotetext{
${ }^{25} \mathrm{We}$ do not consider a usterity carried out in the fourth year of the term, as we only observe 80 governments lasting over the fourth year (about half of the sample). Austerity in the second year is instead included as control
} 
may suggest that the estimated baseline effect is a lower bound of the true electoral cost of taxbased austerity.

\section{B. Strength of Government}

As shown in Table 1, governments with a strong mandate engage more in austerity policies than those with a weak one, all else equal. This is because, presumably, strong governments do not fear to lose the elections despite embracing austerity, while weak governments avoid carrying out austerity because they are afraid of its electoral costs. While we already checked that the results are robust when controlling for the initial strength of the government (Table C4), an interesting question is whether the effect of austerity differs between strong and weak governments.

To examine the role played by the strength of the government, we estimate Equation (1) for the two subsamples of governments with a strong and a weak mandate, defined as in Section III. We also estimate Equation (1) on the two restricted samples of strong and weak governments using the variables capturing the austerity announced in the first year of the government term, for which our definition of strong mandate is more relevant.

The results in Table 6 suggest that governments with a strong mandate are much less affected by tax-based austerity than those with a weak one. Regardless of whether we consider all austerity plans or only those announced in the first year of the term, we estimate a tax-based austerity package worth $1 \%$ of GDP to reduce the vote share by about $5 \%$ for strong governments, but the effect is not statistically different from zero. For governments with a weak mandate, instead, we estimate a negative coefficient of about $-8 \%$ in the case of austerity adopted in any year of the term, while the effect of austerity adopted early in the term is more than double, at $-17 \%$. Both coefficients are statistically significant at the $99 \%$ confidence level. 
Confirming our baseline findings, expenditure-based austerity plans, instead, do not have any significant effect on the vote share, neither for strong nor for weak governments. In line with the finding that strong governments are not penalized for tax-based austerity, voters also reward them for good growth outcomes and do not punish them when the economy is in a recession, while for weak governments the opposite holds. ${ }^{26}$

These results are robust to alternative definitions of government strength and confirm that weak governments are punished badly both if the economy is doing poorly and when they implement tax-based austerity. ${ }^{27}$ Note that since weaker governments tend to refrain from doing austerity (Table 1), the estimated coefficient for the effect of tax-based austerity carried out by weak governments is even likely to be biased upwards (smaller negative effects).

\section{Choice of Doing Austerity}

To further account for the choice of whether to carry out austerity or not and for the size of the package, we next estimate two alternative specifications. In the first, we add a $0 / 1$ dummy to indicate whether any austerity is implemented during the government term to Equation (1). In the second, we augment Equation (1) by including a variable measuring the magnitude of overall austerity (both tax hikes and expenditure cuts) implemented during the term. Note that since these two additional variables control for the choice of carrying out austerity and for the

\footnotetext{
${ }^{26}$ The coefficient for GDP growth in the electoral year is about $5 \%$ for strong governments, while it ranges between $2 \%$ and $3 \%$ for weak ones. Of course, the larger coefficients for strong governments might be driven by periods of recessions. We check that this is not the ca se by replicating Table 6 but allowing GDP growth to have differential effects in recessions (growth below zero) and expansions (growth above zero). The results, presented in Table C6 in Appendix C, confirm that strong governments are rewarded for good growth outcomes, while they a re not punished when the economy is in a recession. Strikingly, instead, weak governments are punished when the economy is in recession buta re not rewarded when it is in expansion.

${ }^{27}$ In Table C7 in Appendix C we replicate Table 6 using the level (rather than the change) of the vote share to mea sure the strength of the mandate and estimate coefficients that are very similar to those obtained when using the change in the vote share.
} 
size of the package, the coefficients for tax- and expenditure-based austerity measure the marginal effects of the composition of austerity. In addition, we also estimate a specification in which we include two dummies to capture all terms in which, respectively, at least one taxand on expenditure-based austerity plan is adopted - these dummies control for the choice of adopting a tax-or expenditure-based plan, while the coefficients for tax- and expenditure-based austerity report the marginal effects of the size of the plans. The results obtained from these exercises are presented in Table 7 and confirm that tax-based austerity is more costly than expenditure-based one.

\section{Inverse propensity score weighting}

As we discussed, the timing of the announcement of austerity over the cycle and the type of austerity may be endogenous, the former to the proximity of elections and the latter to the ideology of the government. Insofar as both the type of austerity and its effect depended on these factors, the differential effect of tax-versus expenditure-based announcements could be estimated with bias. Restricting the sample to episodes of consolidations occurring far from the election (when electoral outcomes are less of a concern for politicians) and including political controls in the regression may be sufficient to estimate unbiased coefficients if the dependence between the outcome and these predictors were linear. To address the possibility that this is not the case, we adopt an inverse propensity weighted regression adjusted estimator, following Jorda and Taylor (2015). ${ }^{28}$ We proceed as follows. First, we classify a term as receiving either an expenditure, tax or no treatment depending on whether consolidation in the

\footnotetext{
${ }^{28}$ Such an estimator, which falls in the class of doubly robust estimators (Imbens 2004; Wooldridge 2007; Lunceford and Davidian 2004; and Kreif et a 1. 2011) has the advantage to be consistent even if either the propensity score or the linear regressions are mis-specified.
} 
firstyear of the term was either tax or expenditure based, if any. ${ }^{29}$ Second, we estimate a Probit model of the occurrence of tax- and expenditure-based austerity on macroeconomic variables (GDP growth, potential output, inflation rate, debt-to-GDP ratio) and political variables (ideology and the strength of the coalition) at the beginning of the government's term as well as their interaction. The results, reported in Table 8 , suggest that expenditure-based plans are more likely to follow higher levels of debt-to-GDP ratio, while tax-based austerity seems to be predicted by the strength of the government. ${ }^{30} \mathrm{Next}$, we perform a linear fit of our outcome of interest, the growth in vote share during the term on the same political and economic controls, including the treatment variables. We then compute the difference in outcomes between the treatments by reweighting the outcomes with the inverse of the propensity score computed with the Probit regression just described. The estimated average treatment effect is reported in Table 9. The results confirm our previous findings: expenditure-based plans are statistically significantly less costly than tax-based ones; and tax-based austerity is significantly costlier relative to years when no consolidation is announced. The coefficients measure the average difference in vote share growth between different treatments, that in this case is about $1.3 \%$ tax- or expenditure-based plan in the first year of term.

\section{EXTENSIONS}

In this section, we present some extensions to our baseline analysis. We explore the role played by (i) the response of the economy to austerity, (ii) the government's ideology, and (iii) the

\footnotetext{
${ }^{29}$ We drop consolidations above the $90^{\text {th }}$ percentile to make expenditure- and tax-based pla ns comparable in size (on a verage around $1.3 \%$ ofGDP).

${ }^{30}$ Following Jorda and Taylor (2015), we replace extreme values of predicted probability with 0.9 and 0.1 .
} 
economic conditions at the time of announcement as potential channels driving the electoral effects of austerity. Further, we also examine the effect of austerity on the probability that the government is dissolved before the end of its mandate.

\section{A. The Response of the Economy to Austerity}

One potential reason for the different electoral consequences of tax- and expenditure-based consolidations could be their different effect on the economy. Indeed, using the same narrative austerity data that we use, a large literature finds tax-based consolidations to induce large and relatively persistent output losses, while expenditure-based consolidations are usually found to have only mild, if any, contractionary effects. To the extent that voters care about macroeconomic performance and income more in general, this differential response might explain why tax-based austerity is more politically costly.

In what follows, we augment the model by adding several indicators of macroeconomic performance during the government term in order to investigate the effect of austerity controlling for the response of the economy, therefore essentially 'shutting down' this potential transmission channel. We consider the average growth rate of GDP and disposable income over the term, as well as the mean yearly change of the unemployment rate, the inflation rate, and the budget balance over the term. Since the literature studying the macroeconomic effects

of austerity has found effects lasting over a 5-year window, here we only focus on austerity carried out in the first year of the government's term, thus allowing for some time for the macroeconomic effects of austerity to fully materialize. Table 10 presents the results. For ease of reference, the baseline results are reported in Column 1. 
The coefficients estimated for the control variables have the expected signs-positive for GDP and disposable income growth as well as the fiscal balance and negative for unemployment and inflation — and they are all statistically significant at standard confidence levels except for the unemployment rate. Looking at tax- and expenditure-based consolidations, their estimated effects on the vote share are not substantially changed. The inclusion of the fiscal balance over the term (Column 5) and of all the macroeconomic variables together (Column 7) only slightly reduces the effect of tax-based consolidations. These results suggests that the response of the economy explain only partially the electoral effects of taxbased consolidations.

\section{B. Ideology}

Partisans models of political economy hold that voters weigh key macroeconomic variables differently according to personal preferences. Crucially, these preferences also matter for the desired size of governments. In this section, we investigate whether the electoral effects of different austerity policies might depend on the political base of the parties implementing them. Tax-based consolidations may carry more negative consequences if decided by right-wing governments, while expenditure-based consolidations should be costlier for left- than rightleaning governments.

We test these hypotheses by interacting our tax- and expenditure-based austerity variables with the ideology variable and estimating Equation (2). We estimate the model using both our overall consolidation variables and those measuring consolidation announcements in the first year of the term. Table 11 presents the results. Column 1 shows our baseline results not accounting for ideology, while Columns 2 and 3 report coefficients obtained estimating 
Equation (2) using, respectively, the overall and the first-year austerity variables. To ease the interpretation of the coefficients, the ideology variable is normalized so that it takes value 1 for the typical right-leaning government. ${ }^{31}$

The results confirm our hypotheses that right -leaning governments are more penalized from tax hikes than expenditure cuts, while the opposite holds for left-leaning governments. We find tax-based consolidations to be very costly for right-leaning governments, whereas their effect tend to be not statistically significant for left-leaning ones. In contrast, expenditurebased consolidations are costly for left-leaning governments but beneficial for right-leaning ones.

We also examined whether the electoral costs of tax-based consolidations carried out by right-leaning governments are larger and statistically different from expenditure-based consolidations from left-leaning governments. The point estimates provide suggestive evidence that electoral costs tend to be larger for tax measures introduced by right government. The F-test of the difference of these electoral effects is statistically significant for the full sample, while it is not for the first year of the government mandate, when strategic considerations are likely to be less relevant.

\section{Macroeconomic Conditions at the Time of Announcements}

Do the electoral effects of austerity depend on the macroeconomic conditions prevailing at the time in which it is announced? In this section, we attempt to answer this question using a smooth transition function as in Auerbach and Gorodnichenko (2012) to calculate the probabilities of being in a low and in a bad state and estimate Equation (3) as discussed in

\footnotetext{
${ }^{31}$ After this normalization, the ideology variable takes value -0.7 for the typical left-leaning government. Its minimum and maximum values are -1.3 and 2.1 respectively.
} 
Section IV. Table 12 reports the results. Column 1 shows the baseline results (Equation 1), while Column 2 lists coefficients obtained estimating Equation (3). Since the ideology of the government is an important driver of the electoral effects of austerity, we also report coefficients estimated from an alternative expanded specification in which we further interact our austerity variables in good and bad states with the ideology variable.

The results offer two main insights. First, austerity policies, and particularly tax increases, tend to reduce the vote share when carried out during bad economic times, regardless of the ideology of the government. Second, the government may increase the vote share by announcing austerity during good economic times, but this depends on the 'who' and the 'how': left-leaning governments gain votes by raising taxes, while right-leaning ones by cutting expenditure. Further, we also find that right-leaning governments lose votes when increasing taxes during good economic times.

\section{Austerity and the Probability of Early Fall of the Government}

In parliamentary systems, governments can be voted out of office through a vote nonconfidence by the parliament, and indeed the average length of the party term is well below that of the legislature, indicating that governments tend to fall earlier than the natural end of their term (see discussion in Appendix B). Here, we analyze whether one reason for governments to fall early is the adoption of austerity policies. We constructan early fall dummy variable, taking value 1 when the government falls before the last 6 months of the legislature and 0 otherwise, and estimate a logistic regression model using our tax- and expenditure-based consolidation variables plus GDP growth in the last 12 months of the government term. Leader's party fixed effects cannot be included since some of them would perfectly predict the 
dependent variable for some parties, thus reducing the sample. In detail, the specification that we estimate is as follows:

$$
\text { EarlyFall }_{i, e}=\alpha+\beta T b_{i, e}+\delta S b_{i, e}+\varphi Y_{i, e}+\varepsilon_{i, e}
$$

where $\operatorname{EarlyF}_{i, e}$ is the dummy capturing instances in which the government falls before the end of the legislature and the rest is as in Equation (1). We also estimate an augmented specification in which we interact the austerity variables with the ideology variable, similarly as in Equation (2). Table 13 reports the results - coefficients are normalized so to express marginal probabilities.

Broadly in line with our results on the effects of austerity on the vote share, we find that tax-based consolidations increase the probability that the government falls before the natural end of the legislature, whereas expenditure-based consolidations do not, on average. In particular, an austerity package worth $1 \%$ of GDP, to be achieved mainly through tax hikes, increases the probability of an early government fall by about $8 \%$. This effect is statistically significant at the $90 \%$ confidence level.

When we estimate the augmented specification accounting for ideology, we find that expenditure-based consolidations reduce the probability of an early fall of the government when implemented by right-leaning parties. Concerning tax-based consolidations, instead, none of the estimated coefficients is statistically different from zero, although the signs are in line with our earlier findings.

The main take-away from this analysis is that tax-based consolidations not only decrease the vote share of the leader's party but also reduce its spell in government. Since when coalition governments fall early it is usually because one or more of the parties pulls out 
from the coalition, these results also nicely provide suggestive evidence as to why only the party of the incumbent leader is punished at the poll after tax-based austerity. The junior parties in the coalition may react to austerity by pulling out from the government when they see that austerity is badly received by the public, thusmaking the main party as responsible and limiting their own electoral fallout.

\section{CONCLUSION}

The electoral effects of fiscal policy choices are difficult to measure. We make progress by using data which allow us to precisely match the announcement of an austerity plan with the government introducing it, and to select only measures that are discretionary and not motivated by the state of the economy, which can be critical for voters' decisions. This approach allows us to obtain much clear-cut and unequivocal results on the electoral consequences of fiscal austerity relative to previous literature.

First, we uncover significant difference in the effects of tax-versus expenditure-based austerity. The former is more costly at the polls even controlling for the more negative effects on growth that it has relative to the latter. Second, we uncover significant ideological differences. Right-leaning governments are less likely to implement tax-based austerity but are punished more severely when they do so. Left-leaning governments are punished less severely when they engage in tax-based austerity but are punished more if they engage in expenditurebased austerity, contrary to the fate of right-wing governments. Third, we find that governments which have a stronger majority are less punished by the voters when they engage in tax-based austerity. 
These facts are consistent with a model where parties are punished for implementing the type of austerity which is further away from their political platform (expenditure cuts for the left and tax hikes for the right), in a population of voters whose median is the tax-payer. Politicians expect this and tend to avoid, when close to elections, tax- at the advantage of expenditure-based austerity.

We also find that the electoral costs of fiscal austerity are larger when tax hikes or expenditure cuts are introduced during periods of weak economic activity. In contrast, fiscal austerity is not typically costly, and can actually be rewarded by voters, if implemented during strong economic conditions. In particular, we find that left-(right-)leaning governments may gain votes by raising taxes (cutting expenditure) in good times. These results have important implications and suggest that fiscal consolidation does not necessarily lead to negative electoral outcomes when political economic considerations related to the 'when' austerity is implemented and by 'who' are internalized. 
FIGURES

Figure 1. The Electoral Cycle of Austerity
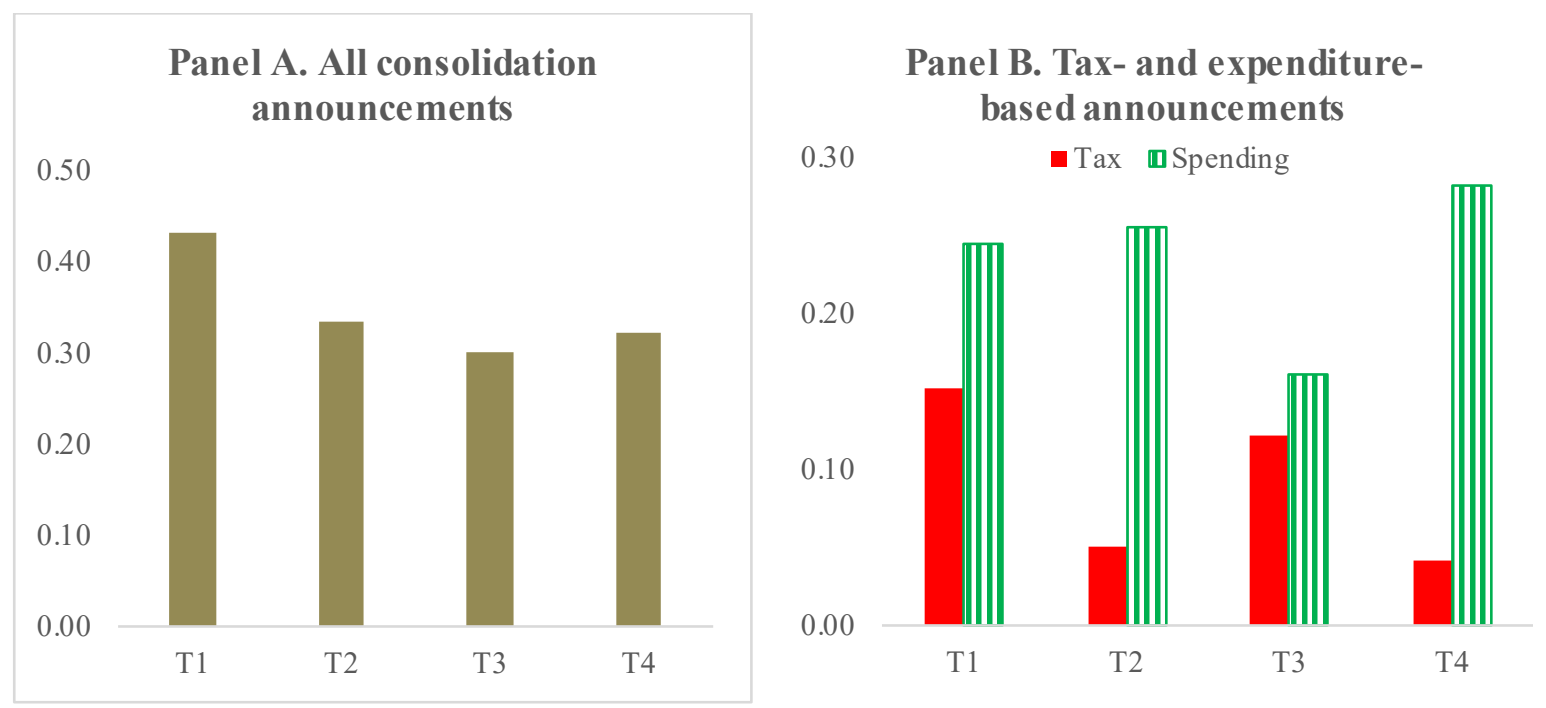

Notes: the figure plots the value of the full sample average consolidation announcement observed over the government term. Panel A reports values for all consolidation announcements, while Panel B distinguishes between tax- (red bars) and expenditure-based announcements (green bars). The y-axis denotes the value of the announcement, while the $\mathrm{x}$-axis denotes the timing (in years).

Figure 2. The Electoral Cycle of Austerity, Distinguishing by Ideology

Panel A. Tax-based

0.40

0.10

0.00

$\mathrm{T} 1$

- Left $\mathbf{n}$ Right

(1)

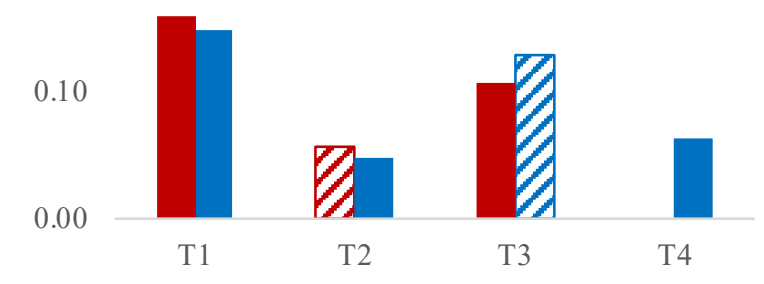

0.40

0.20

0.10

0.00

$\mathrm{T} 1$
Panel B. Expenditure-based

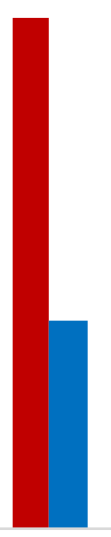

- Left $\mathbf{\text { Right }}$

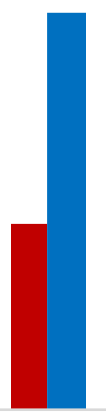

$\mathrm{T} 2$

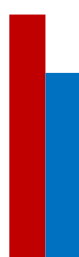

T3

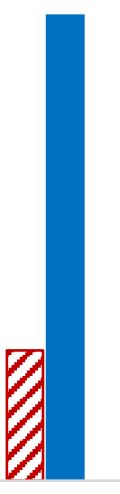

T4

Notes: the figure plots the value of the average consolidation announcement observed over the government term, distinguishing by type of consolidation and ideology of the party of the incumbent leader. Panel A considers tax-based consolidations (tax hikes being larger than expenditure cuts), while Panel B focuses on expenditure-bas ed announcements (expenditure cuts larger than tax hikes). Red (blue) bars report announcements made by governments where the party of the incumbent leader is left- (right-)leaning. Striped bars indicate that the average announcement is not statistically different from zero. The $y$-axis denotes the value of the announcement, while the $\mathrm{x}$-axis denotes the timing (in years). 
TABLES

Table 1. Government Mandate and Austerity Plans

\begin{tabular}{l|cc|cc|cc}
\hline & \multicolumn{2}{|c|}{ Overall } & \multicolumn{2}{c|}{ Tax } & \multicolumn{2}{c}{ Expenditure } \\
& Strong & Weak & Strong & Weak & Strong & Weak \\
\hline \% terms w. austerity & 55.84 & 50.65 & 32.47 & 28.57 & 38.96 & 35.06 \\
Mean total & 1.24 & 0.99 & 0.30 & 0.30 & 0.85 & 0.61 \\
Mean first year & $0.59 * *$ & $0.24 * *$ & $0.19 *$ & $0.06 *$ & $0.39 * *$ & $0.10 * *$ \\
Mean first year - left & $0.99 * *$ & $0.21 * *$ & $0.22^{* *}$ & $0.03 * *$ & $0.78 * *$ & $0.05 * *$ \\
Mean first year - right & 0.40 & 0.25 & 0.18 & 0.08 & 0.21 & 0.12 \\
\hline
\end{tabular}

Notes: the table reports values of the average austerity announcement (in \% of GDP) made by governments with a 'weak' and a 'strong' mandate, distinguishing by the type of consolidation announced (whether tax- or expenditure-based), the ideology of the party of the incumbent leader (whether left- or right-leaning), and the time of the announcement (whether in the first year or across the all sample). Governments with a 'strong' ('weak') mandate are defined as those in which the change in the vote share of the main party at the election that brought the government into power is above (equal to or below) the sample median. *, **,*** indicate that the mean between government with a 'strong' and 'weak' mandate are statistically different from each other at the $90 \%, 95 \%$ and $99 \%$ confidence level, respectively.

Table 2. The Electoral Effects of Austerity

\begin{tabular}{|c|c|c|c|c|c|c|}
\hline & $\begin{array}{c}(1) \\
\text { Party }\end{array}$ & $\begin{array}{c}(2) \\
\text { Party }\end{array}$ & $\begin{array}{c}(3) \\
\text { Party }\end{array}$ & $\begin{array}{c}(4) \\
\text { Coalition } \\
\end{array}$ & $\begin{array}{c}(5) \\
\text { Coalition } \\
\end{array}$ & $\begin{array}{c}(6) \\
\text { Coalition } \\
\end{array}$ \\
\hline Tax & $\begin{array}{c}-7.1^{* * *} \\
(1.6)\end{array}$ & $\begin{array}{c}-8.2 * * * \\
(1.4)\end{array}$ & $\begin{array}{c}-7.3^{* * *} \\
(1.3)\end{array}$ & $\begin{array}{c}-6.3 * * * \\
(1.3)\end{array}$ & $\begin{array}{c}-6.7 * * * \\
(1.3)\end{array}$ & $\begin{array}{c}-5.9 * * * \\
(1.2)\end{array}$ \\
\hline Expenditure & $\begin{array}{c}-0.1 \\
(1.4)\end{array}$ & $\begin{array}{c}0.7 \\
(1.6)\end{array}$ & $\begin{array}{c}0.2 \\
(1.5)\end{array}$ & $\begin{array}{l}-0.9 \\
(0.8)\end{array}$ & $\begin{array}{l}-0.7 \\
(0.8)\end{array}$ & $\begin{array}{l}-1.3 \\
(0.8)\end{array}$ \\
\hline Growth & & & $\begin{array}{c}2.8^{* * * *} \\
(0.9)\end{array}$ & & & $\begin{array}{c}2.6^{* * * *} \\
(0.9)\end{array}$ \\
\hline Obs. & 157 & 157 & 156 & 149 & 149 & 148 \\
\hline $\mathrm{R}^{\wedge} 2$ & 0.08 & 0.12 & 0.20 & 0.10 & 0.14 & 0.24 \\
\hline Party FE & NO & YES & YES & NO & YES & YES \\
\hline \multicolumn{7}{|c|}{$\begin{array}{l}\text { Notes: the table reports the electoral effects of austerity announcements, estimated from Equation (1). } \\
\text { "Tax" and "expenditure" report the } \% \text { change of the vote share of either the governing party (Columns } 1 \text { - } \\
\text { 3) or the coalition of governing parties (Columns } 4-6 \text { ) associated with a tax- and expenditure-based } \\
\text { consolidation announcement worth } 1 \% \text { of GDP, respectively. "Growth" reports the of the vote share } \\
\text { associated with a } 1 \text { p.p. increase in the growth rate in the year of the election. *, } * *, * * * \text { indicate statistical } \\
\text { significance at respectively the } 90 \%, 95 \% \text { and } 99 \% \text { confidence level, based on robust standard errors (in } \\
\text { parenthesis). Specifications in Columns } 1 \text { and } 4 \text { do not include incumbent party fixed effects, while all the } \\
\text { others do. }\end{array}$} \\
\hline
\end{tabular}


Table 3. The Electoral Effects of Austerity for Coalition Governments

\begin{tabular}{|c|c|c|c|}
\hline & $\begin{array}{c}(1) \\
\text { Overall } \\
\text { coalition }\end{array}$ & $\begin{array}{c}(2) \\
\text { Main } \\
\text { party }\end{array}$ & $\begin{array}{c}(3) \\
\text { Rest of } \\
\text { coalition }\end{array}$ \\
\hline Tax & $\begin{array}{c}-6.4 * * * \\
(1.8)\end{array}$ & $\begin{array}{c}-8.7 * * * \\
(2.2)\end{array}$ & $\begin{array}{l}-0.4 \\
(4.6)\end{array}$ \\
\hline Expenditure & $\begin{array}{l}-0.1 \\
(0.7)\end{array}$ & $\begin{array}{c}2.0 \\
(1.9)\end{array}$ & $\begin{array}{l}-3.0 \\
(1.9)\end{array}$ \\
\hline Growth & $\begin{array}{l}1.8^{*} \\
(0.9)\end{array}$ & $\begin{array}{c}2.4 * * \\
(1.1)\end{array}$ & $\begin{array}{c}0.7 \\
(1.6)\end{array}$ \\
\hline Observations & 76 & 76 & 76 \\
\hline R-squared & 0.40 & 0.31 & 0.06 \\
\hline Party FE & YES & YES & YES \\
\hline \multicolumn{4}{|c|}{$\begin{array}{l}\text { Notes: the table reports the electoral effects of a usterity a nnouncements for coalition governments, } \\
\text { estima ted from Equation (1). "Tax" and "expenditure" report the \% change of the vote share of } \\
\text { either the entire government coalition (Column 1), the party of the incumbent leader (Column } 2 \text { ) } \\
\text { or the other parties in the coa lition (Column } 3 \text { ) a ssociated with a tax- and expenditure-based } \\
\text { consolidation announcement worth } 1 \% \text { of GDP, respectively. "Growth" reports the change of the } \\
\text { vote share associated with a } 1 \text { p.p. increase in the growth rate in the year of the election. *, } * *, * * * \\
\text { indicate statistical significa nce at respectively the } 90 \%, 95 \% \text { and } 99 \% \text { confidence level, based on } \\
\text { robust standard errors (in pa renthesis). All specifications include incumbent party fixed effects. }\end{array}$} \\
\hline
\end{tabular}


Table 4. The Electoral Effects of Austerity Using Different Austerity Variables

\begin{tabular}{|c|c|c|c|c|c|c|}
\hline & $\begin{array}{c}(1) \\
\text { Ex-ante } \\
\text { matched }\end{array}$ & $\begin{array}{c}(2) \\
\text { Ex-ante } \\
\text { not match. }\end{array}$ & $\begin{array}{c}(3) \\
\text { Ex-post } \\
\text { not match. }\end{array}$ & $\begin{array}{c}(4) \\
\text { Ex-ante } \\
\text { matched }\end{array}$ & $\begin{array}{c}(5) \\
\text { Ex-ante } \\
\text { not match. }\end{array}$ & $\begin{array}{c}(6) \\
\text { Ex-post } \\
\text { not match. }\end{array}$ \\
\hline Overall & $\begin{array}{l}-1.7 \\
(1.3)\end{array}$ & $\begin{array}{c}0.8 \\
(3.5)\end{array}$ & $\begin{array}{c}6.8 * * * \\
(1.5)\end{array}$ & & & \\
\hline $\operatorname{Tax}$ & & & & $\begin{array}{c}-7.3 * * * \\
(1.3)\end{array}$ & $\begin{array}{l}-4.8^{*} \\
(2.7)\end{array}$ & $\begin{array}{c}4.6 \\
(13.7)\end{array}$ \\
\hline Expenditure & & & & $\begin{array}{c}0.2 \\
(1.5)\end{array}$ & $\begin{array}{c}4.4 \\
(5.3)\end{array}$ & $\begin{array}{c}0.7 \\
(3.3)\end{array}$ \\
\hline Growth & $\begin{array}{c}3.1 * * * \\
(0.9)\end{array}$ & $\begin{array}{c}3.1 * * * \\
(0.9)\end{array}$ & $\begin{array}{c}0.3 \\
(1.4)\end{array}$ & $\begin{array}{c}2.8 * * * \\
(0.9)\end{array}$ & $\begin{array}{c}2.7 * * * \\
(0.9)\end{array}$ & $\begin{array}{c}3.0 * * * \\
(0.7)\end{array}$ \\
\hline Observations & 156 & 156 & 15 & 156 & 156 & 156 \\
\hline R-squared & 0.14 & 0.11 & 0.23 & 0.20 & 0.13 & 0.11 \\
\hline Party FE & YES & YES & YES & YES & YES & YES \\
\hline
\end{tabular}

Notes: the table reports the electoral effects of austerity announcements estimated from Equation 1, using different austerity variables. Columns 1-3 consider overall austerity (without distinguishing between tax hikes and expenditure cuts), while Columns 4-6 make that distinction. Columns 1 and 4 report coefficients estimated using ex-ante austerity measures in which each plan is matched to the government that announced it (as in our baseline). Columns 2 and 5 use ex-ante austerity measures but without matching. Columns 3 and 6 use ex-post, realized, fiscal variables, in which years with austerity are defined as such when the increase in the budget balance is larger than $1.5 \%$ of GDP. By definition, such austerity measures are unmatched. "Growth" reports the change of the vote share associated with a 1 p.p. increase in the growth rate in the year of the election. $*, * *, * * *$ indicate statistical significance at respectively the $90 \%, 95 \%$ and $99 \%$ confidence level, based on robust standard errors (in parenthesis). All specifications include incumbent party fixed effects. 
Table 5. The Electoral Effects of Austerity Announced Early and Late in the Term

\begin{tabular}{|c|c|c|c|c|c|c|}
\hline & $\begin{array}{c}\text { (1) } \\
\text { All years } \\
\text { full sample }\end{array}$ & $\begin{array}{l}\text { (2) } \\
\text { All years } \\
\text { res. sample }\end{array}$ & $\begin{array}{c}(3) \\
1^{\text {st }} \text { year } \\
\text { full sample }\end{array}$ & $\begin{array}{c}(4) \\
1^{\text {st }} \text { year } \\
\text { res. sample }\end{array}$ & $\begin{array}{c}(5) \\
3^{\text {rd }} \text { year }\end{array}$ & $\begin{array}{c}(6) \\
1^{\text {st }} \text { year } \\
\& 3^{\text {rd }} \text { year }\end{array}$ \\
\hline Tax allyears & $\begin{array}{c}-7.3 * * * \\
(1.3)\end{array}$ & $\begin{array}{c}-6.8 * * * \\
(1.5)\end{array}$ & & & & \\
\hline Expenditure allyears & $\begin{array}{c}0.2 \\
(1.5)\end{array}$ & $\begin{array}{l}-0.7 \\
(1.1)\end{array}$ & & & & \\
\hline Tax $1^{\text {st }}$ year & & & $\begin{array}{l}-8.0 * \\
(4.3)\end{array}$ & $\begin{array}{c}-10.1 * * * \\
(3.6)\end{array}$ & & $\begin{array}{c}-10.8 * * * \\
(4.0)\end{array}$ \\
\hline Expenditure $1^{\text {st }}$ year & & & $\begin{array}{c}0.8 \\
(3.2)\end{array}$ & $\begin{array}{l}-1.4 \\
(1.8)\end{array}$ & & $\begin{array}{l}-1.5 \\
(1.9)\end{array}$ \\
\hline Tax $3^{\text {rd }}$ year & & & & & $\begin{array}{c}-6.3 * * \\
(2.3)\end{array}$ & $\begin{array}{c}-6.3 * * \\
(2.6)\end{array}$ \\
\hline Expenditure $3^{\text {rd }}$ year & & & & & $\begin{array}{l}-2.4 \\
(4.2)\end{array}$ & $\begin{array}{l}-5.0 \\
(5.5)\end{array}$ \\
\hline Growth & $\begin{array}{c}2.8 * * * \\
(0.9)\end{array}$ & $\begin{array}{c}2.1^{* *} \\
(0.8)\end{array}$ & $\begin{array}{c}2.7 * * * \\
(0.8)\end{array}$ & $\begin{array}{c}2.1 * * \\
(0.8)\end{array}$ & $\begin{array}{c}1.9 * * \\
(0.9)\end{array}$ & $\begin{array}{l}1.7^{*} \\
(1.0)\end{array}$ \\
\hline Observations & 156 & 119 & 156 & 119 & 119 & 119 \\
\hline R-squared & 0.20 & 0.16 & 0.15 & 0.10 & 0.10 & 0.18 \\
\hline Party FE & YES & YES & YES & YES & YES & YES \\
\hline \multicolumn{7}{|c|}{$\begin{array}{l}\text { Notes: the table reports the electoral effects of austerity announcements depending on the timing of the announcements. } \\
\text { Estimated are obtained from Equation (1). Columns } 1 \text { and } 2 \text { consider all announcements (regardless of timing), but } \\
\text { Column } 2 \text { report estimates obtained from the restricted sample of governments at least over the third year. Columns } 3 \text { and } \\
4 \text { consider austerity announcements made in the first year of the term, with Column } 4 \text { reporting estimates from the } \\
\text { restricted sample only. Column } 5 \text { considers announcements made in the third year, while Column } 6 \text { reports estimates for } \\
\text { austerity announced both in the first and third year (austerity in the second year is also included to control for omitted } \\
\text { variables). All coefficients report the } \% \text { change in the vote share of the party of the incumbent leader associated with the } \\
\text { change in the respective variable considered (a tax- and expenditure-based consolidation announcement worth } 1 \% \text { of GDP } \\
\text { in case of "Tax" and "expenditure", and a } 1 \text { p.p. increase in the growth rate in the electoral year in case of "Growth"). *, } \\
* *, * * * \text { indicate statistical significance at respectively the } 90 \%, 95 \% \text { and } 99 \% \text { confidence level, bas ed on robust standard } \\
\text { errors (in parenthesis). All specifications include incumbent party fixed effects. }\end{array}$} \\
\hline
\end{tabular}


Table 6. The Electoral Effects of Austerity for Strong and Weak Governments

\begin{tabular}{|c|c|c|c|c|c|}
\hline & $\begin{array}{c}\text { (1) } \\
\text { Baseline }\end{array}$ & $\begin{array}{c}(2) \\
\text { Strong } \\
\text { govts } \\
\text { all years } \\
\end{array}$ & $\begin{array}{c}(3) \\
\text { Weak } \\
\text { govts } \\
\text { all years } \\
\end{array}$ & $\begin{array}{c}(4) \\
\text { Strong } \\
\text { govts } \\
1^{\text {st }} \text { year } \\
\end{array}$ & $\begin{array}{c}(5) \\
\text { Weak } \\
\text { govts } \\
1^{\text {st }} \text { year } \\
\end{array}$ \\
\hline Tax all years & $\begin{array}{c}-7.3 * * * \\
(1.3)\end{array}$ & $\begin{array}{c}-5.5 \\
(3.8)\end{array}$ & $\begin{array}{c}-8.2 * * * \\
(1.5)\end{array}$ & & \\
\hline Tax $1^{\text {st }}$ year & & & & $\begin{array}{l}-5.2 \\
(4.5)\end{array}$ & $\begin{array}{c}-17.6^{* * *} \\
(6.2)\end{array}$ \\
\hline Expenditure all years & $\begin{array}{c}0.2 \\
(1.5)\end{array}$ & $\begin{array}{c}0.2 \\
(1.9)\end{array}$ & $\begin{array}{c}0.5 \\
(1.1)\end{array}$ & & \\
\hline Expenditure $1^{\text {st }}$ year & & & & $\begin{array}{c}0.9 \\
(3.9)\end{array}$ & $\begin{array}{c}5.3 \\
(3.4)\end{array}$ \\
\hline Growth & $\begin{array}{c}2.8 * * * \\
(0.9)\end{array}$ & $\begin{array}{l}5.3 * * \\
(2.3)\end{array}$ & $\begin{array}{l}2.2 * * \\
(1.0)\end{array}$ & $\begin{array}{l}5.0 * * \\
(2.3)\end{array}$ & $\begin{array}{c}2.9 * * * \\
(0.9)\end{array}$ \\
\hline Observations & 156 & 76 & 77 & 76 & 77 \\
\hline R-squared & 0.20 & 0.28 & 0.37 & 0.26 & 0.28 \\
\hline Party FE & YES & YES & YES & YES & YES \\
\hline \multicolumn{6}{|c|}{$\begin{array}{l}\text { Notes: the table reports the electoral effects of austerity announcements depending on whether the government has a strong } \\
\text { or a weak mandate. All coefficients are obtained estimating Equation (1). Column } 1 \text { reports baseline estimates, as in } \\
\text { Column } 1 \text { of Table } 2 \text {. Columns } 2 \text { and } 3 \text { report estimates obtained over the restricted sample of governments with a strong } \\
\text { and weak mandate respectively, and considering all austerity announcements, while Columns } 4 \text { and } 5 \text { consider only } \\
\text { austerity announcements made in the first year of government. Governments with a 'strong' ('weak') mandate are defined } \\
\text { as those in which the change in the vote share of the main party at the election that brought the government into power is } \\
\text { above (equal to or below) the sample median. All coefficients report the } \% \text { change in the vote share of the party of the } \\
\text { incumbent leader associated with the change in the respective variable considered (a tax- and expenditure-based } \\
\text { consolidation announcement worth } 1 \% \text { of GDP in case of "Tax" and "expenditure", and a } 1 \text { p.p. increase in the growth } \\
\text { rate in the electoral year in case of "Growth"). *, } * * * * \text { indicate statistical significance at respectively the } 90 \%, 95 \% \\
\text { and } 99 \% \text { confidence level, based on robust standard errors (in parenthesis). All specifications include incumbent party } \\
\text { fixed effects. }\end{array}$} \\
\hline
\end{tabular}


Table 7. The Electoral Effects of Austerity Controlling for the Choice of Doing It

\begin{tabular}{lcccc}
\hline & $(1)$ & $\begin{array}{c}(2) \\
\text { Austerity } \\
\text { dummy }\end{array}$ & $\begin{array}{c}(3) \\
\text { Austerity } \\
\text { variable }\end{array}$ & $\begin{array}{c}\text { Austerity } \\
\text { type dummies }\end{array}$ \\
\hline Tax & $-7.3^{* * *}$ & $-7.2^{* * *}$ & $-9.0^{* * *}$ & $-4.4^{* *}$ \\
Expenditure & $(1.3)$ & $(1.4)$ & $(2.8)$ & $(2.1)$ \\
Dummy austerity & 0.2 & 0.3 & -1.4 & -0.9 \\
Overall austerity & $(1.5)$ & $(1.6)$ & $(2.4)$ & $(2.0)$ \\
& & -0.9 & & \\
Dummy tax-based & & $(3.2)$ & 1.6 & $-7.6^{*}$ \\
Dummy expenditure-based & & & $(2.4)$ & $4.1)$ \\
Growth & & & & $(3.8)$ \\
& & & & $3.0^{* * *}$ \\
Observations & & & & $(0.9)$ \\
R-squared & & & & \\
Party FE & & & & \\
\hline
\end{tabular}

Notes: the table reports the electoral effects of austerity announcements controlling for the choice of announcing it. All coefficients are obtained estimating Equation (1). Column 1 reports baseline estimates, as in Column 1 of Table 2. Columns 2 to 4 report estimates obtained when controlling for the choice of carrying out austerity. Column 2 includes a $0 / 1$ dummy variable taking value equal to 1 when there is at least one austerity announcements during the term. Column 3 also controls for the magnitude of the austerity announcements by including a continuous variable measuring the value of the entire austerity announcements made during the term (in \% of GDP). Column 4 controls for the choice of announcing either taxor expenditure-based austerity by including two $0 / 1$ dummies taking value 1 when there is at least one tax- or expenditurebased announcement during the term, respectively. All coefficients report the $\%$ change in the vote share of the party of the incumbent leader associated with the respective variable considered (a tax- and expenditure-based consolidation announcement worth 1\% of GDP in case of "Tax" and "expenditure", and a 1 p.p. increase in the growth rate in the electoral year in case of "Growth"). ${ }^{*}, * *, * *$ indicate statistical significance at respectively the $90 \%, 95 \%$ and $99 \%$ confidence level, based on robust standard errors (in parenthesis). All specifications include incumbent party fixed effects. 
Table 8. Predictors of Tax and Expenditure based plans in the first year of the term.

(1)

Expenditure-based
(2)

Tax-based

Vote share

0.28

$(0.30)$

$-0.05$

(0.30)

$-2.80$

(16.40)

$-0.09$

(0.10)

1.79

(1.70)

$0.19^{* *}$

(0.10)

$-0.02$

(0.70)

$-3.00$

(2.0)

$-2.35^{*}$

(1.40)

$-0.24$

(0.60)
$0.56 *$

(0.30)

$-0.34$

(0.30)

6.70

(17.1)

0.07

(0.1)

$-0.15$

(1.50)

$-0.02$

(0.1)

0.12

(1.50)

0.96

(2.10)

1.71

(1.50)

$0.83^{*}$

$(0.50)$

Observations

Notes: The table shows marginal effects coefficients of two Probit regressions. In Column 1 (2), the dependent variable is a $0 / 1$ dummy taking value 1 in the event of an expenditure- (tax-)based plan in the first year of the government term. Coefficients are multiplied by 100 for ease of reference. *,**,** indicate statistical significance at respectively the $90 \%$, $95 \%$ and $99 \%$ confidence level, based on robust standard errors (in parenthesis). 
Table 9. Inverse propensity weighted regression adjusted estimator of the ATE

(1)

Tax vs. expenditure
(2)

Expenditure vs no plan
(3)

Tax vs no plan
ATE
$-11.18 * *$
4.16
$-7.02 *$
Observations

\section{5}
145
145
Notes: the table shows the average treatment effect (ATE) of tax- and expenditure-based consolidation plans announced in the first year of the government term on the percent change in the vote share of the party in government at the next election. The ATE is estimated via inverse propensity score weighting of the linear fit of the outcome variable. Column 1 shows the estimated ATE of a tax-based plan relative to an expenditure-based plan; Columns 2 and 3 show the ATE of, respectively, an expenditure- and a tax-based plan relative to a no-plan counterfactual. The propensity score is computed via Probit regression whose marginal effects are shown in Table 12.*,**,*** indicate statistical significance at respectively the $90 \%, 95 \%$ and $99 \%$ confidence level, based on robust standard errors (in parenthesis). 
Table 10. The Response of the Economy as Driver of the Electoral Effects of Austerity

(1)

Growth EY
(2)

Growth

over term
(3)

U. change over term
(4)

CPI change

over term

$-12.1 * * *$

(4.1)
$-14.1 * * *$

(4.8)
(5)

Budget change over term

Disposable income growth

All

1.9

(3.2)

2.0

(3.2)

\section{1}

(3.3)
2.1

1.0

(3.4)

Growth

Unemployment

Inflation

Fiscal budget

Disposable

income
$-7.1 * * *$

(2.5)
143

0.08

YES
$-10.8^{* *}$

(4.2)

$-0.6$

(3.0)
$-11.7 * * *$

(3.9)

1.9

(3.3)
$-11.3 * * *$

(4.0)

$-1.6$

$6.5 * *$

$-1.8$

(1.1)

$5.4 * * *$

$4.3 * * *$

(1.4)

$2.5 *$

$-2.3$

(1.4)

\begin{tabular}{llllllll} 
Observations & 143 & 143 & 143 & 143 & 143 & 143 & 143 \\
R-squared & 0.08 & 0.09 & 0.16 & 0.09 & 0.17 & 0.10 & 0.26 \\
Party FE & YES & YES & YES & YES & YES & YES & YES \\
\hline
\end{tabular}

Notes: the table reports the electoral effects of austerity announcements controlling for macroeconomic developments. All coefficients are obtained estimating Equation (1) using $1^{\text {st }}$ year austerity variables. Column 1 reports estimates when not controlling for the response of the economy. Columns 2 to 5 report estimates obtained when controlling for, in turn, (i) average GDP growth over government term, (ii) the average unemployment rate over the term, (iii) the average inflation rate over the term, and (iv) the average value of the government budget balance over the term. Column 6 reports estimates when all controls are included at the same time. All coefficients report the $\%$ change in the vote share of the party of the incumbent leader as sociated with the respective variable considered. In the case of "tax" and "expenditure" these are a tax- and expenditure-based consolidation announcement worth $1 \%$ of GDP. *, **,*** indicate statistical significance at respectively the $90 \%, 95 \%$ and $99 \%$ confidence level, based on robust standard errors (in parenthesis). All specifications include incumbent party fixed effects. 
Table 11. The Electoral Effects of Austerity after Accounting for Ideology

\begin{tabular}{|c|c|c|c|}
\hline & $\begin{array}{c}(1) \\
\text { No ideology, } \\
\text { any year (baseline) }\end{array}$ & $\begin{array}{c}(2) \\
\text { Ideology, } \\
\text { any year }\end{array}$ & $\begin{array}{l}\text { (3) } \\
\text { Ideology, } \\
\text { first year }\end{array}$ \\
\hline Tax & $\begin{array}{c}-7.6^{* * *} \\
(1.3)\end{array}$ & $\begin{array}{c}-6.0 * * * \\
(1.3)\end{array}$ & $\begin{array}{l}-3.8 \\
(4.2)\end{array}$ \\
\hline Tax*ideology & & $\begin{array}{c}-5.3 * * * \\
(1.7)\end{array}$ & $\begin{array}{c}-5.8^{* * *} \\
(2.7)\end{array}$ \\
\hline Expenditure & $\begin{array}{c}0.5 \\
(1.6)\end{array}$ & $\begin{array}{l}-0.6 \\
(1.0)\end{array}$ & $\begin{array}{c}2.1 \\
(1.6)\end{array}$ \\
\hline Expenditure*ideology & & $\begin{array}{c}4.8^{* * *} \\
(1.5)\end{array}$ & $\begin{array}{c}7.4 * * * \\
(2.2)\end{array}$ \\
\hline Growth & $\begin{array}{c}2.6^{* * * *} \\
(0.9)\end{array}$ & $\begin{array}{c}2.5^{* *} \\
(0.9)\end{array}$ & $\begin{array}{c}2.4 * * * \\
(0.9)\end{array}$ \\
\hline Observations & 148 & 148 & 148 \\
\hline R-squared & 0.20 & 0.30 & 0.23 \\
\hline F-test tax right $=\exp$ left & & 0.00 & 0.33 \\
\hline Party FE & YES & YES & YES \\
\hline \multicolumn{4}{|c|}{$\begin{array}{l}\text { Notes: the table reports the electoral effects of austerity announcements depending on the political leaning of the governing } \\
\text { party. Column } 1 \text { reports baseline coefficients, not controlling for the political leaning, and estimated from Equation (1). } \\
\text { Columns } 2 \text { and } 3 \text { report estimates when accounting for the political leaning, obtained from Equation (2), and considering } \\
\text { austerity announcements made in any year of the government term and in the first year, respectively. Political leaning is } \\
\text { measured through a continuous variable ("Ideology"), taking more positive (negative) values when the party of the } \\
\text { incumbent leader is more right- (left-) leaning. The variable is normalized to take value } 1 \text { for the average right-leaning } \\
\text { party. The rows denoted by "tax" and "expenditure" report the } \% \text { change in the vote share of the party of the incumbent } \\
\text { leader associated with a consolidation announcement worth } 1 \% \text { of GDP, respectively to be achieved mainly through tax } \\
\text { hikes and expenditure cuts, when the party of the incumbent leader is exactly at the centre of the political spectrum. The } \\
\text { rows denoted by "Tax*ideology" and "Expenditure*ideology" report the additional change in the governing party vote } \\
\text { share associated with announcements made by the average right-leaning party. *, **, } * * * \text { indicate statistical significance } \\
\text { at respectively the } 90 \%, 95 \% \text { and } 99 \% \text { confidence level, based on robust standard errors (in parenthesis). The row "F-test } \\
\text { tax right = exp left" reports p-values from the following F-test: Tax+Tax*Ideology = Exp - Exp*Ideology. All } \\
\text { specifications include incumbent party fixed effects. }\end{array}$} \\
\hline
\end{tabular}


Table 12. The Role of Macroeconomic Conditions at the Time of the Announcement

(1)

Any state

no ideology
(2)

High/low states no ideology
(3)

High/low states Ideology
$\operatorname{Tax}$

Tax-high state

Tax-high state*ideology

Tax-low state

Tax-low state*ideology

Expenditure

Expenditure-high state

Expenditure-high state*ideology

Expenditure-low state

Expenditure-low state*ideology

Growth-high state

Growth-low state

Observations

R-squared

Party FE
$-7.2 * * *$

$-8.1$

(5.9)

$-12.7$

$-6.5 * * *$

(1.6)

$-2.2$

0.2

(1.5)

$\begin{array}{ccc} & 4.1 & 4.8^{* *} \\ & (6.5) & (2.3) \\ & & 8.7 * * * \\ & & (2.0) \\ & -3.1 & -4.8^{*} \\ & (4.1) & (2.7) \\ & & 1.1 \\ & & (3.0) \\ 3.3^{*} & 3.0 & 2.4 \\ (1.8) & (1.8) & (1.9) \\ 1.8 & 1.8 & 1.8 \\ (1.8) & (1.8) & (1.8) \\ & & \\ 156 & 156 & 148 \\ 0.20 & 0.22 & 0.34 \\ \text { YES } & \text { YES } & \text { YES }\end{array}$

Notes: the table reports the electoral effects of austerity announcements depending on whether these are announced during periods of high or low economic growth. Column 1 reports baseline coefficients (as in Column 1 ofTable 2), not accounting for the economic cycle. Column 2 report estimates when accounting for the economic cycle, obtained from Equation (3). The state of the cycle is measured through a continuous $0-1$ smooth transition function variable, $G\left(Z_{i, t}\right)$, taking higher values the higher is the probability that economy is in a recession (see Section III for details). Rows denoted by "tax" and "expenditure" report the \% change in the vote share of the party of the incumbent leader as sociated with a consolidation announcement worth $1 \%$ of GDP, respectively to be achieved mainly through tax hikes and expenditure cuts. Rows denoted by "[...]-high state" ("[...]-low state)" report the effect of austerity announcements made when the probability of being in an expansion is $100 \%(0 \%)$, and are obtained interacting the austerity variables with $1-G\left(Z_{i, t}\right)\left(G\left(Z_{i, t}\right)\right.$ ). Column 3 reports results when also accounting for the political leaning of the party of the incumbent leader, measured through a continuous variable ("Ideology"), taking more positive (negative) values when the party of the incumbent leader is more right- (left-) leaning. The variable is normalized to take value 1 for the average right-leaning party. Rows denoted by "[...]*ideology" report the additional change in the governing party vote share associated with announcements made by the average rightleaning party. $* * *, * * *$ indicate statistical significance at respectively the $90 \%, 95 \%$ and $99 \%$ confidence level, based on robust standard errors (in parenthesis). All specifications include incumbent party fixed effects. 
Table 13. The Effect of Austerity on the Probability of an Early Fall of the Government

(1)

No ideology

$\operatorname{Tax}$

Tax*Ideology

Expenditure

Expenditure*Ideology

Growth

$8.1^{*}$

(2)

Ideology

4.0

12.8

$-1.6$

$-8.4^{*}$

$-4.9 * *$

Observations

195

192

Party FE

$\mathrm{NO}$

NO

Pseudo R-squared

0.04

0.06

Notes: the table reports the effects of austerity announcements on the probability that the government falls before the natural end of the legislature, estimated through Equation (4). Column 1 reports unconditional probabilities. The rows denoted by "tax" and "expenditure" report the $\%$ change in the probability of an early fall of government associated with a consolidation announcement worth $1 \%$ of GDP, respectively to be achieved mainly through tax hikes and expenditure cuts. Column 2 reports change in probabilities when also accounting for the political leaning of the party of the incumbent leader, measured through a continuous variable ("Ideology"), taking more positive (negative) values when the party of the incumbent leader is more right- (left-) leaning. The variable is normalized to take value 1 for the average right-leaning party. The rows denoted by "[...]*ideology" report the additional change in the probability of an early fall associated with announcements made by the average right-leaning party. ${ }^{*}, * *, * *$ indicate statistical significance at respectively the $90 \%, 95 \%$ and $99 \%$ confidence level, based on robust standard errors (in parenthesis). 


\section{REFERENCES}

1. Alesina A. \& Furceri, D. \& Ostry, J. D. \& Papageorgiou, C. \& Quinn, D. P. 2020. "Structural Reforms and Elections: Evidence from a World-Wide New Dataset," NBER Working Papers 26720.

2. Alesina A. \& Azzalini, G. \& Favero, C. \& Giavazzi, F. \& Miano, A. "2018. "Is it the "How" or the "When" that Matters in Fiscal Adjustments?," IMF Economic Review, Palgrave Macmillan; International Monetary Fund, vol. 66(1), pages 144-188, March.

3. Alesina, A., Barbiero, O., Favero, C., Giavazzi, F. and Paradisi, M., 2015. Austerity in 2009-13.Economic Policy, 30(83), pp.383-437.

4. Alesina, A.F., Carloni, D. and Lecce, G., 2011. The Electoral consequences of large fiscal adjustments (No. w17655). National Bureau of Economic Research.

5. Alesina, A., Favero, C. and Giavazzi, F., 2019. Austerity: When it Works and when it Doesn't. Princeton University Press.

6. Alesina, A. and Passalacqua, A., 2016. The political economy of government debt. In Handbook of Macroeconomics (Vol. 2, pp. 2599-2651). Elsevier.

7. Alesina, A., Perotti, R., Tavares, J., Obstfeld, M. and Eichengreen, B., 1998. The political economy of fiscal adjustments. Brookings Papers on Economic Activity, 1998(1), pp.197266.

8. Ardanaz, M., Hallerberg, M. and Scartascini, C., 2019. Fiscal Consolidations and Electoral Outcomes in Emerging Economies: Does the Policy Mix Matter? Macro and Micro Level.

9. Arias, E., \& Stasavage, D. (2019). How large are the political costs of fiscal austerity? Journal of Politics.

10. Auerbach, A.J. and Gorodnichenko, Y., 2012. Measuring the output responses to fiscal policy. American Economic Journal: Economic Policy, 4(2), pp.1-27.

11. Battaglini, M., 2011. The political economy of public debt. Annu. Rev. Econ., 3(1), pp.161-189.

12. Battaglini, M. and Coate, S., 2008. A dynamic theory of public spending, taxation, and debt. American Economic Review, 98(1), pp.201-36.

13. Brender, A., 2003. The effect of fiscal performance on local government election results in Israel: 1989-1998. Journal of Public Economics, 87(9-10), pp.2187-2205. 
14. Brender, Adi, and Allan Drazen. 2008. "How Do Budget Deficits and Economic Growth Affect Reelection Prospects? Evidence from a Large Panel of Countries." American Economic Review, 98 (5): 2203-20.

15. Devries, M.P., Guajardo, J., Leigh, M.D., and Pescatori, A., 2011. A new action-based dataset of fiscal consolidation (No. 11-128). International Monetary Fund.

16. Döring, H. and Manow, P., 2012. Parliament and government composition database (ParlGov). An infrastructure for empirical information on parties, elections and governments in modern democracies. Version, 12(10).

17. Döring, H. and Regel, S., 2019. Party Facts: A database of political parties worldwide. Party Politics, 25(2), pp.97-109.

18. Drazen, A. and Mejía Eslava, M.E., 2003. The political business cycle in Colombia on the National and Regional level. Departamento Nacional de Planeación.

19. Drazen, A. and Mejía Eslava, M.E., 2010. Electoral manipulation via voter-friendly spending: Theory and evidence. Journal of development economics 92(1), 39-52.

20. Hübscher, E., 2016. The politics of fiscal consolidation revisited. Journal of Public Policy, 36(4), pp.573-601.

21. Hübscher, E. and Sattler, T., 2017. Fiscal consolidation under electoral risk. European Journal of Political Research, 56(1), pp.151-168.

22. Imbens, Guido W. 2004. Nonparametric Estimation of Average Treatment Effects Under Exogeneity: A Review. Review of Economics and Statistics 86(1): 4-29

23. Jones, M.P., Meloni, O. and Tommasi, M., 2012. Voters as fiscal liberals: Incentives and accountability in federal systems. Economics \& Politics, 24(2), pp.135-156.

24. Jordà, Òscar, and Alan M. Taylor. "The time for austerity: estimating the average treatment effect of fiscal policy." The Economic Journal 126.590 (2016): 219-255.

25. Kreif, Noemi, Richard Grieve, Rosalba Radice, and Jasjeet S. Sekhon. ' 2013. Regression-Adjusted Matching and Double-Robust Methods for Estimating Average Treatment Effects in Health Economic Evaluation. Health Services and Outcomes Research Methodology 13(2-4): 174-202

26. Lunceford, Jared K., and Marie Davidian. 2004. Stratification and Weighting via the Propensity Score in Estimation of Causal Treatment Effects: A Comparative Study. Statistics in Medicine 23(19): 2937-60

27. Passarelli, F. and Tabellini, G., 2017. Emotions and political unrest. Journal of Political Economy 125(3), pp.903-946. 
28. Peltzman, S., 1992. Voters as fiscal conservatives. The Quarterly Journal of Economics 107(2), pp.327-361.

29. Ponticelli, J. and Voth, H.J., 2020. Austerity and anarchy: Budget cuts and social unrest in Europe, 1919-2008. Journal of Comparative Economics 48(1), pp.1-19.

30. Powell, G. Bingham, and Guy D. Whitten. 1993. “A Cross-National Analysis of Economic Voting: Taking Account of the Political Context." American Journal of Political Science 37(2): 391-414.

31. Ramey, V.A. and Zubairy, S., 2018. Government spending multipliers in good times and in bad: evidence from US historical data. Journal of Political Economy 126(2), pp.850901.

32. Romer, C.D. and Romer, D.H., 2010. The macroeconomic effects of tax changes: estimates based on a new measure of fiscal shocks. American Economic Review 100(3), pp.763-801.

33. Weingast, B.R., Shepsle, K.A. and Johnsen, C., 1981. The political economy of benefits and costs: A neoclassical approach to distributive politics. Journal of Political Economy 89(4), pp.642-664.

34. Wooldridge, Jeffrey M. 2007. Inverse Probability Weighted M-Estimation for General Missing Data Problems. Journal of Econometrics 141(2): 1281-1301. 


\section{APPENDIX A.}

\section{Description of Alesina et al. (2019) Austerity Dataset}

In this appendix we describe the dataset of fiscal shocks, and the criterion of selection of the measures contained in it. Exhaustive information can be found both in Chapter 6 and the online narrative appendix of Alesina et al. (2019).

\section{Overview}

The original dataset records fiscal adjustment plans announced between 1978 and 2014 in 16 OECD countries (Australia, Austria, Belgium, Canada, Denmark, Finland, France, Germany, Ireland, Italy, Japan, Portugal, Spain, Sweden, the United Kingdom, and the United States. Fiscal plans are composed by a collection of measures. For each measure, the year of implementation, the budgetary impact, a broad description and classification of the type of measure are provided. In particular, the measures are classified into 27 categories. In our main analysis, we aggregate measures into two coarse categories: measures that change expenditure versus those that change taxes. Measures announced at year $t$ can be scheduled to be implemented in the same year or in the following 5. Fiscal plans are composed by a collection of measures. for each of which the year of implementation, the budgetary impact, a broad description and classification are provided. In particular, the measures are classified into 27 categories. In our main analysis, we aggregate measures into two coarse categories: measures that change expenditure versus those that change taxes. Measures announced at year $t$ can be scheduled to be implemented in the same year or in the following 5. Table C2 provides an example of measures announced by Canada in 2011, to be implemented in the same year and in the subsequent ones (magnitudes are expressed in billions of Canadian dollars). 
For each of the fiscal plans, in addition to what done by the authors, we check whether it was announced in a year in which there was a change in government. For each time that that was the case, we reconstruct the month of the announcement of the plan. We construct the independent variables used in the main specification by summing up, for a given announcement date, all the measures announced in that period to be implemented either immediately or in the future. We then classify the whole announcement to be either expenditure- or tax-based, depending on whether announced changes in taxes are larger than changes in expenditures.

\section{Sources}

Fiscal measures are extracted from a variety of sources. In the earliest part of the sample, the same sources as in Devries et al. (2011) are used, including Budget Reports and Speeches, Stability and Convergence Programmes submitted by EU governments to the European Commission, Central Bank Reports, OECD Economic Surveys, and IMF Reports. The dataset also relies from country specific documents such as reports by the Congressional Budget Office and the Economic Reports of the President for the United States; the Journal Officiel de la Republique Francaise for France; etc.

\section{Selection of exogenous measures}

The criterion used to select measures exogenous to the current state of the economy follows Romer and Romer (2010) and Devries et al. (2011). The former selects fiscal adjustments motivated by the aim of improving long-run growth or the aim of reducing an inherited deficit. The dataset that we use only classifies adjustments as such if the deficit-driven adjustment is 
larger than the long-run growth-driven adjustment. The motivation of a fiscal adjustment, when made explicit, is contained in the sources mentioned above. In the creation of the dataset, the authors select a measure only if the plans containing it was introduced with clear sentences that attributed the approved measure either to the aim of correcting the dynamics of some budgetary item (such as pension reforms aimed at reducing outlays), or to the aim of addressing the dynamics of the debt-to-GDP ratio, or the deficit.

For those plans which contain both deficit increasing and deficit reducing measures, the following procedure has been adopted:

- Verify that the total amount of exogenous deficit reducing measures is smaller than the total of the deficit increasing measures. In doing this, consider all deficit increasing measures, both exogenous and endogenous, to avoid the possibility of labelling as a period of adjustment one in which the exogenous fiscal contractions was more than compensated by other expansionary fiscal measures, independently of their motivation.

- If expansionary measures dominate, then the episode is considered as a fiscal expansions and is dropped.

- If, instead, the sum of (the budgetary impact) of all expansionary measures (endogenous and exogenous) was smaller than the impact of all exogenous contractionary measures (announced at $t$ or previously and yet to be implemented), the episode is recorded in the dataset

- The size of the contraction is computed as the difference between the size of the exogenous contractionary measures minus the exogenous expansionary measures.

Exceptionally, this procedure also yielded some rare episodes of deficit increasing announcements: the reason is that, in previous years, there had been contractionary 
announcements large enough to overcome the new expansionary measures introduced during the year considered. These cases however are very rare. 


\section{APPENDIX B.}

\section{Construction of electoral variables}

The underlying electoral data come from multiple sources. We use the electoral dataset compiled by Alesina et al. (2020) to retrieve the dates of each general election, as well as the start and end dates of each government's term in office. We exclude interim and technocratic governments, and governments whose main supporting party did not run at the next election. ${ }^{32}$ We then use information on governments' start and end dates to construct a variable capturing the period featuring the same governing party (or coalition of parties) within the same legislature. ${ }^{33}$

All countries in our sample, except France and the United States, have parliamentary systems in which the head of state has largely a ceremonial role. Hence, we only consider parliamentary elections for these countries. For the United States, we only consider presidential elections as the president is also the head of government. In France, voters elect both the president and the parliament, and both the president and the head of government have executive powers. However, since presidential elections typically attract a higher turnout, we focus on presidential elections.

For countries with parliamentary systems, we rely on Wikipedia and Doring and Manow (2019) to reconstruct the party or coalition of parties supporting the government. Since in parliamentary systems there can be multiple governments within the same legislature, we treat governments within the same legislature that are not supported by the same parties as

\footnotetext{
32 There are five interim governments in our sample (Boeynants and Verhosdaft III in Belgium, Aoki and Ito in Japan and Pintasilgo in Portugal), three technocratic governments (Ciampi, Dini and Monti governments in Italy), and one case in which the main party supporting the government did not run at the next election (the Amato I cabinet in Italy). These governments are excluded.

${ }^{33}$ Governing parties are defined as such if they hold Cabinet seats in the government (Minis tries).
} 
belonging to different party terms. ${ }^{34}$ For instance, in Germany the Social Democratic Party (SPD) formed a coalition government with the Free Democratic Party (FDP) in October/1980. The FDP then pulled out of the coalition in September/1981 and formed a new government with the Christian Democratic Union (CDU) and the Christian Social Union (CSU). Hence, we identify two party terms: the SPD-FDP term, from October/1980 to September/1981, and the CDU-CSU-FDP term, from September/1981 to March/1983. In these and similar cases we have two observations for each election held to account for the different party terms. ${ }^{35}$

In many other instances, different governments within the same legislature are supported by the same parties. For example, in the United Kingdom, Margaret Thatcher and John Mayor were heads of two different Conservative Party governments in the June/1987 to April/1992 legislatures. In this and other similar cases, we record only a single party term (and thus we have only one observation for each election). Turning to presidential systems, given that the same president stays on for a fixed amount of time, we simply retrieve the party to which he or she belongs and record the party term as the term of the president.

To measure electoral performance, we rely on the dataset of Doring and Manow (2019) to collect information on the vote share obtained by the party of the chief executive at the two elections defining the start and the end of the legislature and derive its percent change. ${ }^{36} \mathrm{We}$ also construct a variable measuring the vote share change of the overall coalition of governing

\footnotetext{
${ }^{34}$ In parliamentary systems voters typically elect the parliament rather than the head of government. The government needs to obtain a vote of confidence by the parliament and can be voted out of office through a motion of non-confidence. Similarly, when the prime minister resigns, a new government can be formed without that a new election takes place.

35 There are only seven cases in which we record two distinct party terms in the same legislature (in Germany between 1980 and 1983, Denmark between 1982-1984 and again between 1991 and 1994, Italy between 1994 and 1996, and again between 2008 and 2013, Ireland between 1992 and 1997 and Japan between 1993 and 1996. The results do not hinge on the inclusion of these cases.

${ }^{36}$ Among parliamentary systems, we only collect data for elections in the lower house. For France and the United States, we consider presidential elections. Since data on presidential elections are not available in Doring and Manow (2019) we rely on Wikipedia to collect this additional information. Data on parliamentary seats are not collected for these two countries.
} 
parties, as well as similar other variables to be used in some robustness checks: (i) the vote share change at the previous election, (ii) the percentage point (rather than percent) vote share change, (iii) the percent change in parliamentary seats (rather than vote) share, and (iv) the election turnout. From Doring and Manow (2019), we also source a variable measuring the political leaning (ideology in short) of the party and normalize it to range between -10 and 10 . This variable takes value 0 for the center of the political spectrum and higher (lower) values for more right-(left-)leaning parties.

Table B1 presents basic descriptive statistics of our main variables. Our dataset contains 157 observations (party-terms), ranging from 5 in France to 14 in Japan. There is at least one austerity announcement in 80 cases-slightly more than $50 \%$ of the sample. The average length of the government term is the highest in the United Kingdom (4.4 years) and the lowest in Denmark and Japan (2.5 years). For most countries, it is well below the statutory length of the legislature, an indication that parliaments tend to be dissolved early. There is a large cross-country variation in the vote share of the party of the incumbent leader, with Belgium having the lowest, at $17.8 \%$, and Spain having the highest, at $42.1 \%$. As expected, the vote share correlates negatively with the number of governing parties. Belgium and Italy have the largest number of governing parties, 4.7 and 4.6 respectively on average, while Canada, Spain and the United Kingdom typically feature single-party governments. ${ }^{37}$

Finally, we note that right-leaning governments are more common in almost all countries of our sample. The variable capturing the ideology of the leader's party takes value 0 for the political center and more negative (positive) values for more left- (right-)leaning

\footnotetext{
37 The United Kingdom and Spain recently had coalition governments (the Cons.-Lib. Dem. 2010-2015 government in the United Kingdom and the PSOE-Podemos 2020-government in Spain). As our austerity data ends in 2014 these are not included in our sample.
} 
governments. Its sample average is 1.4 and only Spain has a negative mean. The countries with the most right-leaning governments are Japan and Canada (5.2 and 2.5, respectively). The next section zooms in on the austerity data and discusses how consolidation announcements are distributed during the government term.

Table B1. Descriptive Statistics

\begin{tabular}{l|cccccc}
\hline Country & Obs. & $\begin{array}{c}\text { Terms } \\
\text { with } \\
\text { austerity }\end{array}$ & $\begin{array}{c}\text { Term } \\
\text { length }\end{array}$ & $\begin{array}{c}\text { Vote } \\
\text { share }\end{array}$ & $\begin{array}{c}\text { \# of } \\
\text { parties }\end{array}$ & Ideology \\
\hline Australia & 12 & 4 & 2.7 & 41.3 & 1.4 & 0.7 \\
Austria & 10 & 5 & 3.3 & 39.1 & 1.9 & 0.4 \\
Belgium & 10 & 7 & 3.3 & 17.5 & 4.7 & 0.2 \\
Canada & 10 & 5 & 3.2 & 40.4 & 1.0 & 2.5 \\
Denmark & 13 & 6 & 2.5 & 27.7 & 2.5 & 1.7 \\
Finland & 8 & 3 & 3.9 & 24.7 & 3.8 & 0.3 \\
France & 5 & 4 & $/$ & 26.4 & $/$ & 1.6 \\
Germany & 10 & 8 & 3.3 & 35.5 & 2.7 & 0.9 \\
Ireland & 11 & 4 & 2.8 & 40.7 & 1.7 & 1.9 \\
Italy & 8 & 6 & 3.5 & 30.8 & 4.6 & 1.4 \\
Japan & 14 & 7 & 2.5 & 37.5 & 2.0 & 5.2 \\
Portugal & 11 & 6 & 2.8 & 40.1 & 1.5 & 0.7 \\
Spain & 9 & 6 & 3.6 & 42.1 & 1.0 & -0.1 \\
Sweden & 11 & 3 & 3.2 & 32.9 & 2.0 & 0.1 \\
UK & 7 & 4 & 4.4 & 41.4 & 1.0 & 2.2 \\
USA & 8 & 5 & $/$ & 50.8 & $/$ & $/$ \\
\hline
\end{tabular}




\section{APPENDIX C.}

\section{Robustness Checks}

We start by checking that the results are not driven by a single political party or country and estimate Equation (1) excluding, respectively, one party and one country at a time. Figure C1 reports the results, which are always very close to our baseline. In Table $\mathrm{C} 1$, we show estimates obtained using alternative dependent variables. In particular, we consider: (i) the percentage point (rather than percent) change of the vote share, (ii) the percent change, as well as (iii) the percentage point change of the parliamentary seats share. In Table C2, we report estimates obtained using alternative sets of explanatory variables. We first use a $50 \%$ and a $60 \%$ threshold to differentiate between tax- and expenditure-based announcements (instead of $55 \%$ ). We then use $0 / 1$ tax- and expenditure-based dummies for terms in which there is at least one tax- and one expenditure-based plan, respectively. Third, we also construct variables in which we collapse together all the austerity plans announced during the government term and constrain a term to be either tax- or expenditure-based. Finally, we consider implementation rather than announcement and use variables capturing all the austerity that is implemented by the government in charge (rather than announced). In all cases, the results confirm our main finding that tax-based consolidations carry large electoral costs, while expenditure-based ones are neutral.

We then check that the results (i) are robust to the exclusion of the post-Great Financial Crisis (GFC) period, (ii) are similar in the more recent part of the sample (the 1990-2014 period), (iii) are not driven by short-lived governments - that is, with term lower than 12 months - and (iv) are valid also for (a) the subsample of governments that served a substantial part of the legislature (with term larger than 36 months), (b) the subsample of outgoing governments, and (c) the subsample of parliamentary systems (thus excluding France and the 
US). The results, reported in Table C3, are very similar to the baselines. The only noteworthy differences are for the pre-GFC subsample, for which we estimate tax-based consolidations to have smaller negative effects (at about $-6 \%$, rather than $-7 \%$ ), and for the 1990-2014 subsample, for which the coefficient is more negative, at $-9 \%$.

Next, we assess whether the results are affected by the inclusion of a set of political control variables. Precisely, we consider: (i) the lagged vote share change and (ii) the level of the vote share at the last election to mitigate endogeneity due to the fact that stronger governments do more austerity (Table 1); (iii) the election turnout, as a proxy of how similar the platforms of different political parties are, which should affect turnout and might also affect the performance of the incumbent party; (iv) the number of parties forming the government; and (v) the government's tenure (in months). The results, shown in Table C4, are again very similar to our baseline.

In Table C5, we present the result obtained when we include several macroeconomic controls. We first account for the fact that governments implementing austerity might have inherited a dire fiscal situation and include, in turn, the level of the government debt, the budget balance and the 10 -year real sovereign interest rate at the beginning of the term. ${ }^{38}$ Second, we account for the fact that austerity announcements might have been implemented in response to market pressures and include the change over the government term of the 10 -year real yield. Third, we also control for the output gap and the unemployment rate at the time of the election,

\footnotetext{
${ }^{38}$ These variables also control for the following possibility. Imagine that a newly-elected government refrains from carrying out a usterity immediately after the election, even if the optimal fiscal policy is to modestly do so. Then market pressure builds up and the government is forced to announce austerity. This proves to be a belated remedy the problem and the government lose the upcoming election because of the fiscal situation. In this case, it might be that it was the lack of austerity in beginning of its term; not the belated increase to have caused the electoraldefeat.
} 
which may influence the electoral performance of the incumbent government. We then control for the possibility that austerity announcements might be correlated with the implementation of other types of structural reforms and add the change, over the term, of several reform indicators (Table C6). The reforms that we consider are in the areas of (i) capital account restrictions, (ii) tariff barriers to trade, (iii) domestic financeregulations, and (iv) labor markets (firing) restrictions. The results from these specifications are very similar and not statistically different from the baseline. All in all, these analyses suggest that our main finding that taxbased consolidations carry important electoral costs, while expenditure-based consolidations are neutral on average, are robust. 
Figure C1. Robustness Checks - Party and Country Sample Stability
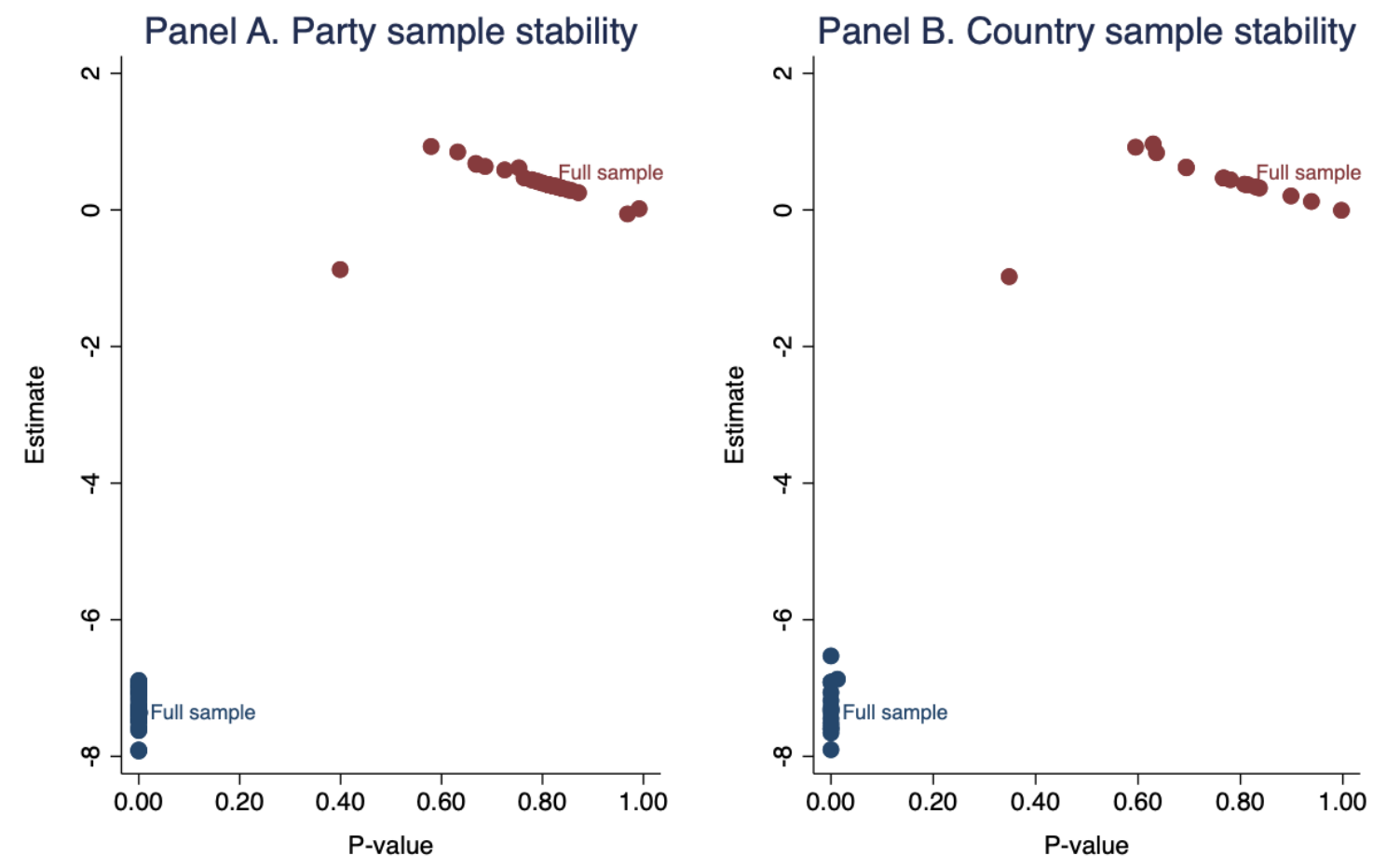

\section{Tax-based Spending-based}

Notes: the figure reports results from a robustness check on sample stability, obtained from Equation (1). Panel A reports estimates when excluding one party at a time, while Panel B reports estimates when excluding one country at a time. Blue (red) dots denote coefficients estimated for consolidation announcements when tax hikes (expenditure cuts) are larger than expenditure cuts (tax hikes). The $y$-axis report point estimates, while the $\mathrm{x}$-axis report $\mathrm{p}$-values. 
Table C1. Robustness Checks on Baseline Analysis - Dependent Variable

\begin{tabular}{|c|c|c|c|c|}
\hline & $\begin{array}{c}(1) \\
\% \text { vote share } \\
\text { (baseline) }\end{array}$ & $\begin{array}{c}\text { (2) } \\
\text { p.p. } \\
\text { vote share }\end{array}$ & $\begin{array}{c}(3) \\
\% \\
\text { seats share }\end{array}$ & $\begin{array}{c}\text { (4) } \\
\text { p.p. } \\
\text { seats share }\end{array}$ \\
\hline Tax & $\begin{array}{c}-7.3 * * * \\
(1.3)\end{array}$ & $\begin{array}{c}-2.6 * * * \\
(0.5)\end{array}$ & $\begin{array}{c}-8.9 * * * \\
(1.5)\end{array}$ & $\begin{array}{c}-3.9 * * * \\
(0.7)\end{array}$ \\
\hline Expenditure & $\begin{array}{c}0.4 \\
(1.5)\end{array}$ & $\begin{array}{l}-0.4 \\
(0.4)\end{array}$ & $\begin{array}{c}0.3 \\
(1.7)\end{array}$ & $\begin{array}{l}-0.4 \\
(0.4)\end{array}$ \\
\hline Growth & $\begin{array}{c}2.7 * * * \\
(0.9)\end{array}$ & $\begin{array}{c}1.0 * * * \\
(0.3)\end{array}$ & $\begin{array}{c}3.5 * * * \\
(1.2)\end{array}$ & $\begin{array}{c}1.5 * * * \\
(0.5)\end{array}$ \\
\hline Observations & 156 & 156 & 142 & 142 \\
\hline R-squared & 0.20 & 0.23 & 0.23 & 0.25 \\
\hline Party FE & YES & YES & YES & YES \\
\hline \multicolumn{5}{|c|}{$\begin{array}{l}\text { Notes: the table reports the electoral effects of austerity announcements estimated using different measures of } \\
\text { electoral effects. Column } 1 \text { reports baseline results using the } \% \text { change in the vote share of the party of the } \\
\text { incumbent leader (as in Column } 1 \text { of Table } 2 \text { ). Column } 2 \text { considers the percentage point change. Column } 3 \\
\text { uses the } \% \text { change in seats share of the party of the incumbent leader, while Column } 4 \text { focuses on the } \\
\text { percentage point change in the seats share. All estimates are from Equation (1). *, } * *, * * * \text { indicate statistical } \\
\text { significance at respectively the } 90 \%, 95 \% \text { and } 99 \% \text { confidence level, based on robust standard errors (in } \\
\text { parenthesis). All specifications include incumbent party fixed effects. }\end{array}$} \\
\hline
\end{tabular}

Table C2. Robustness Checks on Baseline Analysis - Explanatory Variables

\begin{tabular}{|c|c|c|c|c|c|c|}
\hline & $\begin{array}{c}(1) \\
\text { \% vote share } \\
\text { (baseline) }\end{array}$ & $\begin{array}{c}(2) \\
50 \% \\
\text { threshold }\end{array}$ & $\begin{array}{c}(3) \\
60 \% \\
\text { threshold }\end{array}$ & $\begin{array}{c}\text { (4) } \\
\text { Austerity } \\
\text { dummies }\end{array}$ & $\begin{array}{c}(5) \\
\text { Tax or } \\
\text { expenditure }\end{array}$ & $\begin{array}{c}(6) \\
\text { Implemented } \\
\text { austerity }\end{array}$ \\
\hline Tax & $\begin{array}{c}-7.3 * * * \\
(1.3)\end{array}$ & $\begin{array}{c}-6.4 * * * \\
(1.3)\end{array}$ & $\begin{array}{c}-7.2 * * * \\
(1.3)\end{array}$ & $\begin{array}{c}-12.0 * * * \\
(2.8)\end{array}$ & $\begin{array}{c}-4.0 * * \\
(1.7)\end{array}$ & $\begin{array}{c}-9.3 * * * \\
(1.5)\end{array}$ \\
\hline Expenditure & $\begin{array}{c}0.2 \\
(1.5)\end{array}$ & $\begin{array}{c}0.1 \\
(1.5)\end{array}$ & $\begin{array}{l}-0.4 \\
(1.6)\end{array}$ & $\begin{array}{c}2.2 \\
(3.6)\end{array}$ & $\begin{array}{l}-1.5 \\
(1.4)\end{array}$ & $\begin{array}{c}1.5 \\
(1.7)\end{array}$ \\
\hline Growth & $\begin{array}{c}2.8 * * * \\
(0.9)\end{array}$ & $\begin{array}{c}2.7 * * * \\
(0.9)\end{array}$ & $\begin{array}{c}2.9 * * * \\
(0.8)\end{array}$ & $\begin{array}{c}3.2 * * * \\
(0.8)\end{array}$ & $\begin{array}{c}3.0 * * * \\
(0.9)\end{array}$ & $\begin{array}{c}2.8 * * * \\
(0.9)\end{array}$ \\
\hline Observations & 156 & 156 & 156 & 156 & 156 & 156 \\
\hline R-squared & 0.20 & 0.19 & 0.20 & 0.20 & 0.15 & 0.22 \\
\hline Party FE & YES & YES & YES & YES & YES & YES \\
\hline \multicolumn{7}{|c|}{$\begin{array}{l}\text { Notes: the table reports the electoral effects of austerity announcements estimated using different measures of austerity } \\
\text { announcements. Column } 1 \text { reports baseline results obtained differentiating each austerity announcement in either tax- or } \\
\text { expenditure-based, respectively defined so when } 55 \% \text { of more of the austerity measures are either tax hikes or expenditure } \\
\text { cuts (announcements in which tax hikes are between } 45 \% \text { and } 55 \% \text { are not included), and measured in } \% \text { of GDP. Columns } \\
2 \text { and } 3 \text { report results obtained when } 50 \% \text { and } 60 \% \text { thresholds are used instead. Column } 4 \text { reports results obtained when using } \\
0 / 1 \text { dummies for tax- and expenditure-based announcements rather than variables measuring the full extent of the } \\
\text { consolidations announced. Column } 5 \text { reports results when pooling all announcements made during the government term into } \\
\text { one. Column } 6 \text { focuses instead on the austerity implemented during the government term rather than austerity announced. All } \\
\text { estimates are from Equation ( } 1 \text { ). } * * *, * * * \text { indicate statistical significance at respectively the } 90 \%, 95 \% \text { and } 99 \% \text { confidence } \\
\text { level, based on robust standard errors (in parenthesis). All specifications include incumbent party fixed effects. }\end{array}$} \\
\hline
\end{tabular}


Table C3. Robustness Checks on Baseline Analysis - Subsamples

\begin{tabular}{|c|c|c|c|c|c|c|c|}
\hline & $\begin{array}{c}\text { (1) } \\
\text { Full sample } \\
\text { (baseline) }\end{array}$ & $\begin{array}{l}\text { (2) } \\
\text { Up to } 2008 \\
\text { period }\end{array}$ & $\begin{array}{c}(3) \\
\text { Post-1990 } \\
\text { period }\end{array}$ & $\begin{array}{c}\text { (4) } \\
\text { 12-month } \\
\text { min. term }\end{array}$ & $\begin{array}{c}(5) \\
\text { 36-month } \\
\text { min. term }\end{array}$ & $\begin{array}{l}\text { (6) } \\
\text { Outgoing } \\
\text { govts. }\end{array}$ & $\begin{array}{c}(7) \\
\text { Parl. } \\
\text { systems }\end{array}$ \\
\hline Tax & $\begin{array}{c}-7.3 * * * \\
(1.3)\end{array}$ & $\begin{array}{c}-6.0 * * \\
(2.4)\end{array}$ & $\begin{array}{c}-9.0 * * * \\
(1.5)\end{array}$ & $\begin{array}{c}-7.5 * * * \\
(1.5)\end{array}$ & $\begin{array}{c}-7.2 * * * \\
(1.4)\end{array}$ & $\begin{array}{c}-7.5 * * * \\
(1.3)\end{array}$ & $\begin{array}{c}-7.2 * * * \\
(1.3)\end{array}$ \\
\hline Exp. & $\begin{array}{c}0.4 \\
(1.5)\end{array}$ & $\begin{array}{c}0.6 \\
(2.0)\end{array}$ & $\begin{array}{l}-1.6 \\
(1.2)\end{array}$ & $\begin{array}{c}0.6 \\
(1.5)\end{array}$ & $\begin{array}{l}-0.5 \\
(1.0)\end{array}$ & $\begin{array}{c}0.3 \\
(1.5)\end{array}$ & $\begin{array}{c}0.6 \\
(1.6)\end{array}$ \\
\hline Growth & $\begin{array}{c}2.7 * * * \\
(0.9)\end{array}$ & $\begin{array}{l}2.4^{*} \\
(1.2)\end{array}$ & $\begin{array}{c}3.4 * * \\
(1.3)\end{array}$ & $\begin{array}{c}3.0 * * * \\
(0.9)\end{array}$ & $\begin{array}{c}1.8 * * * \\
(0.6)\end{array}$ & $\begin{array}{c}2.6 * * * \\
(0.9)\end{array}$ & $\begin{array}{c}2.4 * * \\
(0.9)\end{array}$ \\
\hline Obs. & 156 & 133 & 98 & 145 & 134 & 149 & 143 \\
\hline $\mathrm{R}^{\wedge} 2$ & 0.20 & 0.12 & 0.30 & 0.21 & 0.19 & 0.20 & 0.20 \\
\hline Party FE & YES & YES & YES & YES & YES & YES & YES \\
\hline \multicolumn{8}{|c|}{$\begin{array}{l}\text { Notes: the table reports the electoral effects of austerity announcements estimated across different sample. Column } \\
1 \text { reports baseline - full sample - results, as in Column } 1 \text { of Table } 2 \text {. Columns } 2 \text { and } 3 \text { report results obtained focusing } \\
\text { on the pre- } 2009 \text { and post- } 1990 \text { periods, respectively. Column } 4 \text { and } 5 \text { report results estimated over the restricted } \\
\text { sample of government lasting at least } 12 \text { and } 36 \text { months respectively. Column } 6 \text { only considers outgoing governments } \\
\text { (still in charge when the election takes place) and excludes earlier governments in the legislature. Column } 7 \text { focuses } \\
\text { on parliamentary systems (excluding the U.S. and France). All estimates are from Equation (1). } *, * * * * * \text { indicate } \\
\text { statistical significance at respectively the } 90 \%, 95 \% \text { and } 99 \% \text { confidence level, based on robust standard errors (in } \\
\text { parenthesis). All specifications include incumbent party fixed effects. }\end{array}$} \\
\hline
\end{tabular}


Table C4. Robustness Checks on Baseline Analysis - Political Control Variables

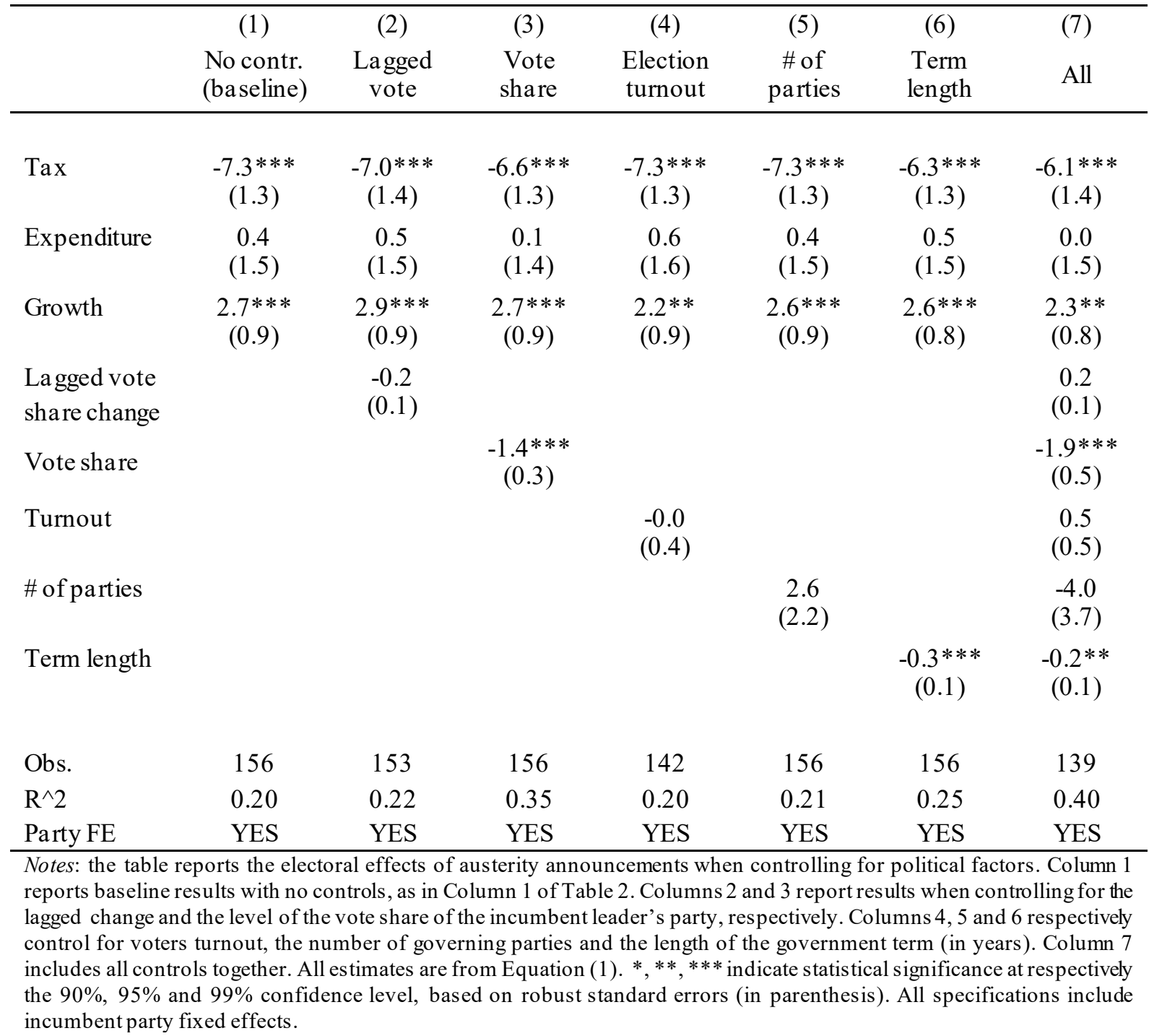


Table C5. Robustness Checks on Baseline Analysis - Macroeconomic Control Variables

\begin{tabular}{|c|c|c|c|c|c|c|c|c|}
\hline & $\begin{array}{c}(1) \\
\text { No control } \\
\text { (baseline) }\end{array}$ & $\begin{array}{c}(2) \\
\text { Debt } \\
\text { level }\end{array}$ & $\begin{array}{c}\text { (3) } \\
\text { Budget } \\
\text { balance }\end{array}$ & $\begin{array}{c}(4) \\
\text { 10-year } \\
\text { level }\end{array}$ & $\begin{array}{c}(5) \\
\text { 10-year } \\
\text { change }\end{array}$ & $\begin{array}{l}(6) \\
\text { All }\end{array}$ & $\begin{array}{c}\text { (7) } \\
\text { Output } \\
\text { gap }\end{array}$ & $\begin{array}{c}(8) \\
\text { Unempl. } \\
\text { rate }\end{array}$ \\
\hline Tax & $\begin{array}{c}-7.3 * * * \\
(1.3)\end{array}$ & $\begin{array}{c}-7.0 * * * \\
(1.4)\end{array}$ & $\begin{array}{c}-7.2 * * * \\
(1.4)\end{array}$ & $\begin{array}{c}-8.3^{* * *} \\
(1.9)\end{array}$ & $\begin{array}{c}-8.0^{* * *} \\
(1.7)\end{array}$ & $\begin{array}{c}-7.7 * * * \\
(1.8)\end{array}$ & $\begin{array}{c}-8.1 * * * \\
(1.4)\end{array}$ & $\begin{array}{c}-8.4 * * * \\
(1.8)\end{array}$ \\
\hline Expenditure & $\begin{array}{c}0.2 \\
(1.5)\end{array}$ & $\begin{array}{c}0.2 \\
(1.6)\end{array}$ & $\begin{array}{l}-0.2 \\
(1.4)\end{array}$ & $\begin{array}{c}0.6 \\
(1.6)\end{array}$ & $\begin{array}{c}0.4 \\
(1.6)\end{array}$ & $\begin{array}{c}0.5 \\
(1.5)\end{array}$ & $\begin{array}{c}1.0 \\
(1.7)\end{array}$ & $\begin{array}{c}1.6 \\
(1.7)\end{array}$ \\
\hline $\begin{array}{l}\text { Growth } \\
\text { at election }\end{array}$ & $\begin{array}{c}2.8 * * * \\
(0.9)\end{array}$ & $\begin{array}{c}2.9 * * * \\
(0.9)\end{array}$ & $\begin{array}{c}2.7 * * * \\
(0.8)\end{array}$ & $\begin{array}{c}3.3 * * * \\
(1.1)\end{array}$ & $\begin{array}{l}3.2 * * * \\
(0.9)\end{array}$ & $\begin{array}{c}3.6^{* * * *} \\
(1.1)\end{array}$ & & \\
\hline $\begin{array}{l}\text { Debt level } \\
\text { at start term }\end{array}$ & & $\begin{array}{l}0.1 * * \\
(0.0)\end{array}$ & & & & $\begin{array}{c}0.1 * * \\
(0.0)\end{array}$ & & \\
\hline $\begin{array}{l}\text { Fiscal balance } \\
\text { at start term }\end{array}$ & & & $\begin{array}{l}-0.7 \\
(0.5)\end{array}$ & & & $\begin{array}{l}-0.4 \\
(0.7)\end{array}$ & & \\
\hline $\begin{array}{l}\text { 10-year real yield } \\
\text { at start term }\end{array}$ & & & & $\begin{array}{l}-0.5 \\
(1.1)\end{array}$ & & $\begin{array}{l}-1.0 \\
(1.1)\end{array}$ & & \\
\hline $\begin{array}{l}\text { 10-year real yield } \\
\text { change during term }\end{array}$ & & & & & $\begin{array}{l}-0.3 \\
(1.6)\end{array}$ & $\begin{array}{l}-1.4 \\
(1.3)\end{array}$ & & \\
\hline $\begin{array}{l}\text { Output gap } \\
\text { at election }\end{array}$ & & & & & & & $\begin{array}{c}0.4 \\
(0.5)\end{array}$ & \\
\hline $\begin{array}{l}\text { Unemployment rate } \\
\text { at election }\end{array}$ & & & & & & & & $\begin{array}{c}-1.1 * * \\
(0.5)\end{array}$ \\
\hline Observations & 156 & 156 & 156 & 150 & 150 & 150 & 157 & 154 \\
\hline R-squared & 0.20 & 0.21 & 0.21 & 0.21 & 0.20 & 0.23 & 0.12 & 0.15 \\
\hline Party FE & YES & YES & YES & YES & YES & YES & YES & YES \\
\hline
\end{tabular}


Table C6. Robustness Checks on Baseline Analysis - Structural Reform Variables

\begin{tabular}{|c|c|c|c|c|c|c|}
\hline & $\begin{array}{c}1) \\
\text { No controls } \\
\text { (ba seline) }\end{array}$ & $\begin{array}{c}(2) \\
\text { Capital } \\
\text { account }\end{array}$ & $\begin{array}{c}(3) \\
\text { Trade } \\
\text { tariffs } \\
\end{array}$ & $\begin{array}{c}\text { (4) } \\
\text { Domestic } \\
\text { finance } \\
\end{array}$ & $\begin{array}{c}(5) \\
\text { Labor } \\
\text { market }\end{array}$ & $\begin{array}{l}6) \\
\text { All }\end{array}$ \\
\hline $\operatorname{Tax}$ & $\begin{array}{c}-7.3 * * * \\
(1.3)\end{array}$ & $\begin{array}{c}-6.4 * * * \\
(1.3)\end{array}$ & $\begin{array}{c}-7.3 * * * \\
(1.3)\end{array}$ & $\begin{array}{c}-7.4 * * * \\
(1.4)\end{array}$ & $\begin{array}{c}-7.3 * * * \\
(1.3)\end{array}$ & $\begin{array}{c}-6.8 * * * \\
(1.5)\end{array}$ \\
\hline Expenditure & $\begin{array}{c}0.2 \\
(1.5)\end{array}$ & $\begin{array}{l}-0.3 \\
(1.7)\end{array}$ & $\begin{array}{c}0.2 \\
(1.5)\end{array}$ & $\begin{array}{c}0.3 \\
(1.5)\end{array}$ & $\begin{array}{c}0.2 \\
(1.5)\end{array}$ & $\begin{array}{l}-0.2 \\
(1.7)\end{array}$ \\
\hline Growth & $\begin{array}{c}2.8 * * * \\
(0.9)\end{array}$ & $\begin{array}{c}2.4 * * * \\
(0.6)\end{array}$ & $\begin{array}{c}2.8 * * * \\
(0.9)\end{array}$ & $\begin{array}{c}2.6 * * * \\
(0.8)\end{array}$ & $\begin{array}{c}2.8 * * * \\
(0.9)\end{array}$ & $\begin{array}{c}2.2 * * * \\
(0.7)\end{array}$ \\
\hline KA reform & & $\begin{array}{l}-0.0 \\
(0.1)\end{array}$ & & & & $\begin{array}{c}0.1 \\
(0.2)\end{array}$ \\
\hline Tariff reform & & & $\begin{array}{c}0.0 \\
(0.9)\end{array}$ & & & $\begin{array}{c}-1.4 * * \\
(0.7)\end{array}$ \\
\hline Finance reform & & & & $\begin{array}{c}0.6 \\
(0.4)\end{array}$ & & $\begin{array}{c}0.2 \\
(0.3)\end{array}$ \\
\hline Labormarket reform & & & & & $\begin{array}{c}0.0 \\
(0.3)\end{array}$ & $\begin{array}{l}-0.6 \\
(0.4)\end{array}$ \\
\hline Observations & 156 & 142 & 156 & 156 & 156 & 142 \\
\hline R-squared & 0.20 & 0.20 & 0.20 & 0.22 & 0.20 & 0.22 \\
\hline Party FE & YES & YES & YES & YES & YES & YES \\
\hline
\end{tabular}


Table C7. Strong and Weak Governments in Recessions and Expansions

\begin{tabular}{|c|c|c|c|c|c|}
\hline & $\begin{array}{c}(1) \\
\text { Ba seline }\end{array}$ & $\begin{array}{l}(2) \\
\text { Strong govts } \\
\text { all years }\end{array}$ & $\begin{array}{c}\quad(3) \\
\text { Weak govts } \\
\text { all years }\end{array}$ & $\begin{array}{l}\text { (4) } \\
\text { Strong govts } \\
\text { first year }\end{array}$ & $\begin{array}{l}\text { (5) } \\
\text { Weak govts } \\
\text { first year }\end{array}$ \\
\hline Tax & $\begin{array}{c}-7.3 * * * \\
(1.3)\end{array}$ & $\begin{array}{l}-5.9 \\
(4.0)\end{array}$ & $\begin{array}{c}-8.1 * * * \\
(1.7)\end{array}$ & & \\
\hline Tax 1st year & & & & $\begin{array}{l}-5.2 \\
(4.7)\end{array}$ & $\begin{array}{c}-17.1^{* *} \\
(7.0)\end{array}$ \\
\hline Expenditure & $\begin{array}{c}0.4 \\
(1.5)\end{array}$ & $\begin{array}{l}-0.1 \\
(1.8)\end{array}$ & $\begin{array}{c}0.5 \\
(1.2)\end{array}$ & & \\
\hline Expenditure 1st year & & & & $\begin{array}{c}0.3 \\
(3.9)\end{array}$ & $\begin{array}{l}5.7^{*} \\
(3.4)\end{array}$ \\
\hline Growth - expansions & $\begin{array}{l}2.6^{*} \\
(1.4)\end{array}$ & $\begin{array}{l}6.5^{*} \\
(3.4)\end{array}$ & $\begin{array}{l}1.0 \\
(1.3)\end{array}$ & $\begin{array}{l}6.1^{*} \\
(3.4)\end{array}$ & $\begin{array}{c}2.6 \\
(1.6)\end{array}$ \\
\hline Growth - recessions & $\begin{array}{l}2.9 \\
(2.4)\end{array}$ & $\begin{array}{l}-0.8 \\
(7.8)\end{array}$ & $\begin{array}{c}4.9 * * \\
(2.2)\end{array}$ & $\begin{array}{c}0.0 \\
(8.2)\end{array}$ & $\begin{array}{l}3.9^{*} \\
(2.2)\end{array}$ \\
\hline Observations & 156 & 76 & 77 & 76 & 77 \\
\hline R-squared & 0.20 & 0.30 & 0.37 & 0.27 & 0.28 \\
\hline Party FE & YES & YES & YES & YES & YES \\
\hline
\end{tabular}

Notes: the table reports the electoral effects austerity announcements as well as those of GDP growth depending on whether the government has a strong or a weak mandate and the timing of the austerity announcements. All coefficients are obtained estimating Equation (1). In all specifications the effect of GDP growth is allowed to change depending on whether growth is negative or positive. Column 1 pools together all governments, regardless of the strength of the mandate, and considers all austerity announcements. Columns 2 and 3 report coefficients estimated over the restricted sample of governments with a strong and weak mandate respectively and consider any announcement, while Columns 4 and 5 only focuses on austerity announced in the first year of the term. Governments with a 'strong' ('weak') mandate are defined as those in which the change in the vote share of the main party at the election that brought the government into power is above (equal to or below) the sample median. ${ }^{*}, * *, * * *$ indicate statistical significance at respectively the $90 \%, 95 \%$ and $99 \%$ confidence level, based on robust standard errors (in parenthesis). All specifications include incumbent party fixed effects. 
Table C8. Robustness Check on the Electoral Effects of Austerity for Strong and Weak Governments

(1)

Bas

$\operatorname{Tax}$

$-7.3 * * *$

(2)

Baseline

Stronggovts

all years

(3)

Weak govts

all years

$-4.8 * * *$

(1.5)

Tax 1st year

Expenditure

0.4
$(1.5)$

(1.5)

$-1.4$

(1.4)

Expenditure 1st year

Growth

$2.7 * * *$

(0.9)

$2.0 * *$

(0.9)

156

0.20

YES
$-11.5 * * *$

(3.1)
(4)

Stronggovts

first year

(5)

Weak govts first year

\begin{tabular}{lccccc} 
Observations & 156 & 76 & 80 & 76 & 80 \\
R-squared & 0.20 & 0.27 & 0.31 & 0.08 & 0.38 \\
Party FE & YES & YES & YES & YES & YES \\
\hline
\end{tabular}

Notes: the table reports the electoral effects of austerity announcements depending on whether the government has a strong or a weak mandate. All coefficients are obtained estimating Equation (1). Column 1 reports baseline estimates, as in Column 1 of Table 2. Columns 2 and 3 report estimates obtained over the restricted sample of governments with a strong and weak mandate respectively, and considering all austerity announcements, while Columns 4 and 5 consider only austerity announcements made in the first year of government. Governments with a 'strong' ('weak') mandate are defined as those in which the level of the vote share of the main party obtained at the election that brought them into power is above (equal to or below) the sample median. $*, * *, * *$ indicate statistical significance at respectively the $90 \%, 95 \%$ and $99 \%$ confidence level, based on robust standard errors (in parenthesis). All specifications include incumbent party fixed effects. 